

\section{COFFEE IN HEALTH AND DISEASE PREVENTION}


This page intentionally left blank 


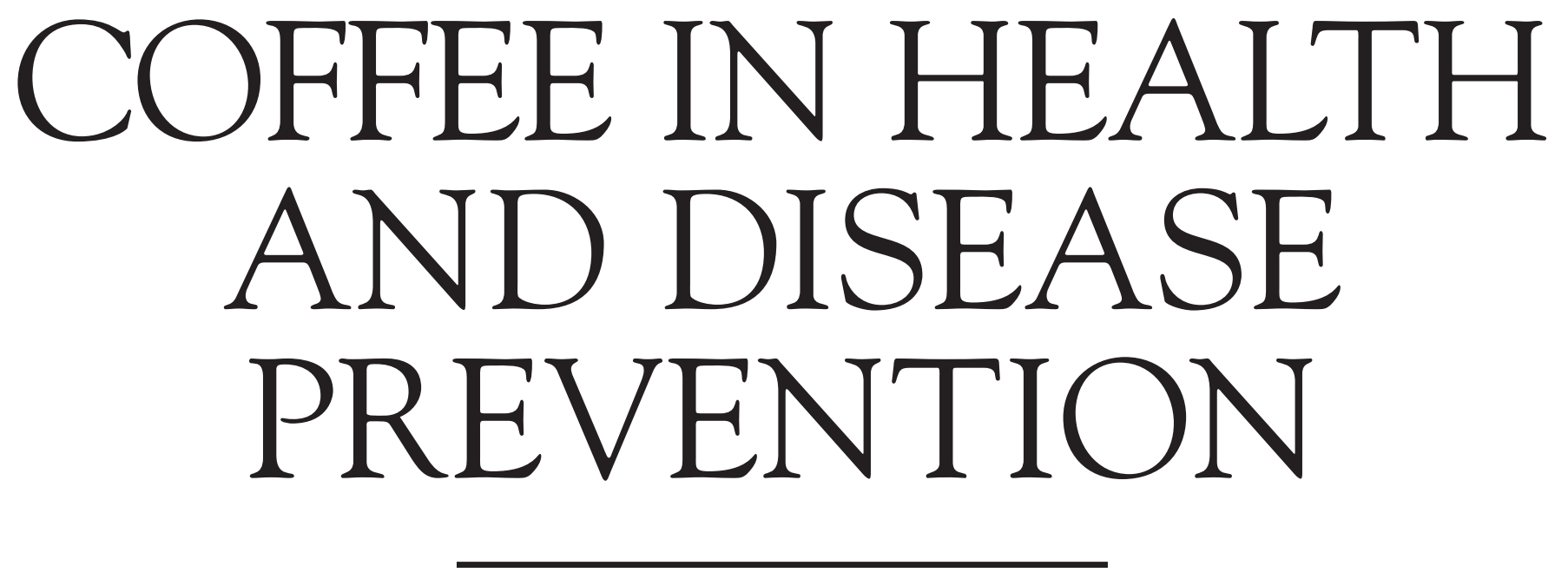

Edited by

Victor R. PReEdy

Department of Nutrition and Dietetics, King's College London, London, UK 
Academic Press is an imprint of Elsevier

32 Jamestown Road, London NW1 7BY, UK

525 B Street, Suite 1800, San Diego, CA 92101-4495, USA

225 Wyman Street, Waltham, MA 02451, USA

The Boulevard, Langford Lane, Kidlington, Oxford OX5 1GB, UK

Copyright (c) 2015 Elsevier Inc. All rights reserved.

Medicine is an ever-changing field. Standard safety precautions must be followed, but as new research and clinical experience broaden our knowledge, changes in treatment and drug therapy may become necessary or appropriate. Readers are advised to check the most current product information provided by the manufacturer of each drug to be administered to verify the recommended dose, the method and duration of administrations, and contraindications. It is the responsibility of the treating physician, relying on experience and knowledge of the patient, to determine dosages and the best treatment for each individual patient. Neither the publisher nor the authors assume any liability for any injury and/or damage to persons or property arising from this publication.

No part of this publication may be reproduced or transmitted in any form or by any means, electronic or mechanical, including photocopying, recording, or any information storage and retrieval system, without permission in writing from the publisher. Details on how to seek permission, further information about the Publisher's permissions policies and our arrangements with organizations such as the Copyright Clearance Center and the Copyright Licensing Agency, can be found at our website: www.elsevier.com/permissions.

This book and the individual contributions contained in it are protected under copyright by the Publisher (other than as may be noted herein).

\section{Notices}

Knowledge and best practice in this field are constantly changing. As new research and experience broaden our understanding, changes in research methods, professional practices, or medical treatment may become necessary.

Practitioners and researchers must always rely on their own experience and knowledge in evaluating and using any information, methods, compounds, or experiments described herein. In using such information or methods they should be mindful of their own safety and the safety of others, including parties for whom they have a professional responsibility.

To the fullest extent of the law, neither the Publisher nor the authors, contributors, or editors, assume any liability for any injury and/or damage to persons or property as a matter of products liability, negligence or otherwise, or from any use or operation of any methods, products, instructions, or ideas contained in the material herein.

ISBN: 978-0-12-409517-5

British Library Cataloguing-in-Publication Data

A catalogue record for this book is available from the British Library

Library of Congress Cataloging-in-Publication Data

A catalog record for this book is available from the Library of Congress

For information on all Academic Press publications

visit our website at http:/ / store.elsevier.com/

Typeset by TNQ Books and Journals

www.tnq.co.in

Printed and bound in United States of America

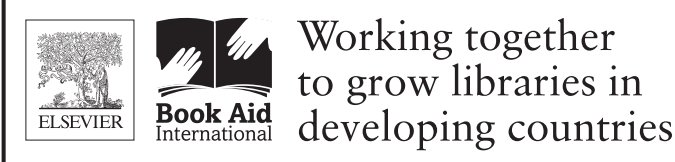

www.elsevier.com • www.bookaid.org 


\section{Contents}

Contributors $\mathrm{xxi}$

Preface xxix

Biography xxxi

\section{SECTION 1}

\section{INTRODUCTORY AND GENERAL TEXT}

\section{Part 1.1 The Plant}

1. The Coffee Plant and Beans: An Introduction ADRIANA FARAH, THIAGO FERREIRA DOS SANTOS

1.1 The Plant 5

1.2 Green Coffee Production 7

1.3 Summary Points 9

References 10

2. Highlights in the History of Coffee Science Related to Health

MARIA LETÍCIA GALLUZZI BIZZO, ADRIANA FARAH, JULIE ANN KEMP, LUIZA BERGUININS SCANCETTI

2.1 Introduction 11

2.2 Coffee, Health, and Science 11

2.3 Main Bioactive Substances in Coffee 13

2.4 Implications of the Amount Consumed 13

2.5 Coffee and Associated Habits 14

2.6 Effects Related to Organs and Diseases 14

2.7 Coffee and Nutrition 15

2.8 Concluding Remarks 16

2.9 Summary Points 16

References 16

3. Plant Biochemistry: Trigonelline Biosynthesis in Coffea arabica and Coffea canephora HIROSHI ASHIHARA

3.1 Introduction 19

3.2 Secondary Metabolites Produced in Coffee Plants 19

3.3 Occurrence of Trigonelline 20

3.4 Biosynthesis of Trigonelline 20

3.5 Degradation of Trigonelline 22

3.6 Physiological Aspects of Trigonelline Metabolism in Coffee 22

3.7 Summary Points 27

References 27
4. Coffea Genome Organization and Evolution

PERLA HAMON, SERGE HAMON, NOROSOA J. RAZAFINARIVO, ROMAIN GUYOT, SONJA SILJAK-YAKOVLEV, EMMANUEL COUTURON, DOMINIQUE CROUZILLAT, MICHEL RIGOREAU, SÉLASTIQUE AKAFFOU, JEAN-JACQUES RAKOTOMALALA, ALEXANDRE DE KOCHKO

4.1 Introduction 29

4.2 Genomic Divergence 29

4.3 Genetic Diversity Based on Transposable

Elements 34

4.4 Summary Points 36

References 36

5. Caffeine-free Species in the Genus Coffea

PERLA HAMON, JEAN-JACQUES RAKOTOMALALA, SÉLASTIQUE AKAFFOU, NOROSOA J. RAZAFINARIVO, EMMANUEL COUTURON, ROMAIN GUYOT, DOMINIQUE CROUZILLAT, SERGE HAMON, ALEXANDRE DE KOCHKO

5.1 Introduction 39

5.2 Caffeine Content, Botanical Classification, and Geographical Distribution of the Species 39

5.3 Genetic Control of Caffeine Biosynthesis 43

5.4 Caffeine Content and Duration of the FloweringFructification Period 43

5.5 Summary Points 44

References 44

6. Characterization of Coffee Genes Involved in Isoprenoid and Diterpene Metabolic

Pathways

LUIZ FILIPE PROTASIO PEREIRA, SUZANA TIEMI IVAMOTO

6.1 Introduction 45

6.2 Overview of the Isoprenoid Metabolic

Pathway 45

6.3 Chemical Composition and Biochemical Analysis of Diterpenes 47

6.4 Regulatory Enzymes and Candidate Genes Involved in Isoprenoid and Diterpene Biosynthesis 48

6.5 Conclusions 50

6.6 Summary Points 51

References 51

7. Botanical Aspects of the Antioxidant System in Coffee IGOR CESARINO, PAULO MAZZAFERA

7.1 Introduction 53

7.2 Conclusions 59

References 59 
8. Coffee Industry in India: Production to Consumption-A Sustainable Enterprise NAYANI SURYA PRAKASH, JEENA DEVASIA, JAYARAMA, RAMESH KUMAR AGGARWAL

8.1 Introduction 61

8.2 Overview of Indian Coffee Industry 61

8.3 Trends in Coffee Exports and Consumption 62

8.4 Indian Coffees: Quality Perspective 62

8.5 History of Coffee Cultivation in India and Early Cultivated Varieties 62

8.6 Unique Features of Coffee Cultivation in India 63

8.7 Genetic Resources and Diversity of Coffee Gene Pool 64

8.8 Coffee Germplasm in India 64

8.9 Molecular Characterization of Representative Coffee Germplasm Available in India 65

8.10 Coffee Species Endemic to India 65

8.11 Taxonomic Status of Indigenous Psilanthus Species Compared with Coffea Species 65

8.12 Growth Habit and Agronomic Traits of Interest of Indigenous Coffee Species 66

8.13 Genetic Improvement and Commercially Grown Varieties in Indian Context 66

8.14 Future Perspective 67

8.15 Summary Points 69

References 69

\section{Part 1.2 Coffee Processing}

9. Coffee Beans and Processing MAIK KLEINWÄCHTER, GERHARD BYTOF, DIRK SELMAR

9.1 Introduction 73

9.2 The Mode of Processing Influences Coffee Quality 73

9.3 Coffee Seeds Exhibit Active Metabolism during Processing 75

9.4 Seed Germination in the Course of Green Coffee Processing 76

9.5 Green Coffee Beans Suffer Drought Stress while Drying 77

9.6 Material Differences in Differently Processed Green Coffees 78

9.7 Deliberately Influencing the Metabolism of Green Coffee to Improve Its Quality 78

9.8 Conclusion 80

9.9 Summary Points 80 References 80

10. Chemical Changes in the Components of Coffee Beans during Roasting FEIFEI WEI, MASARU TANOKURA

10.1 Introduction 83

10.2 Components in Roasted Coffee Beans 83

10.3 The Roasting Degrees 83

10.4 Changes of Carbohydrates 84

10.5 Changes of Chlorogenic Acids 85

10.6 Changes of Trigonelline 87
10.7 Changes of Proteins and Free Amino Acids 87

10.8 Formation of Aroma Components 88

10.9 Torrefacto Roasting 90

References 90

11. Generating Biomedical Polyphenolic Compounds from Spent Coffee or Silverskin

SOLANGE I. MUSSATTO

11.1 Introduction 93

11.2 Polyphenolic Compounds in Spent Coffee and Silverskin and Benefits for Human Health 93

11.3 Extraction of Phenolic Compounds from Natural Sources 97

11.4 Technologies for Extraction of Polyphenolic Compounds from Spent Coffee 98

11.5 Technologies for Extraction of Polyphenolic Compounds from Coffee Silverskin 102

11.6 Conclusions 102

11.7 Summary Points 104

References 104

\section{Authentication of Coffee Blends}

NATALE G. FREGA, DEBORAH PACETTI, MASSIMO MOZZON, MICHELE BALZANO

12.1 Introduction 107

12.2 Chromatography-Based Analytical Techniques 108

12.3 Spectroscopy-Based Analytical Techniques 113

12.4 Genetic Engineering-Based Analytical Techniques 114

12.5 Summary Points 115

References 115

\section{Part 1.3 Constituents and Composition}

\author{
13. Unsaponifiable Matter of Coffee \\ DEBORAH PACETTI, PAOLO LUCCI, NATALE G. FREGA
}

13.1 Introduction 119

13.2 Analytical Techniques for Oil Extraction and Unsaponifiable Matter Analysis 120

13.3 Composition of Coffee Oil 121

13.4 Unsaponifiable Matter Composition: Influence of Coffee Species and Roasting Process 122

13.5 Summary Points 126

References 126

14. Volatile Chemicals from Thermal Degradation of Less Volatile Coffee Components

TAKAYUKI SHIBAMOTO

14.1 Introduction 129

14.2 Volatile Chemicals Formed from Lipids in Coffee 130

14.3 Volatile Chemicals Formed from Carbohydrates and Sugars in Coffee 131

14.4 Volatile Chemicals Formed in Coffee by Maillard Reaction 132 
14.5 Volatile Compounds Formed from Amino Acids and Proteins 132

14.6 Volatile Chemicals Formed from Quinic Acid, Caffeic Acid, and Chlorogenic Acids 133

14.7 Summary Points 134

References 134

\section{Phenolic Compounds in Coffee Compared to Other Beverages}

MAURICIO A. ROSTAGNO, RENATA M.S. CELEGHINI, ISABEL C.N. DEBIEN, GISLAINE C. NOGUEIRA, MARIA ANGELA A. MEIRELES

15.1 Introduction 137

15.2 Phenolic Compounds in Coffee 137

15.3 Phenolic Compounds in Tea 139

15.4 Phenolic Compounds in Wine 140

15.5 Phenolic Compounds in Fruit Juices 140

15.6 Concluding Remarks 141

15.7 Summary Points 141

References 141

\section{Isoflavones in Coffee}

RITA C. ALVES, CRISTINA M.D. SOARES, M. BEATRIZ P.P. OLIVEIRA

16.1 Introduction 143

16.2 Isoflavones in Coffee 143

16.3 Conclusion 147

16.4 Summary Points 148

Acknowledgments 148

References 148

\section{Organic Compounds in Green Coffee} Beans

FEIFEI WEI, MASARU TANOKURA

17.1 Introduction 149

17.2 Composition of Green Coffee Beans 149

17.3 Caffeine 149

17.4 Trigonelline 150

17.5 Chlorogenic Acids 150

17.6 Organic Acids 150

17.7 Sucrose and Other Reducing Sugars 151

17.8 Polysaccharides 151

17.9 Protein and Amino Acids 159

17.10 Lipids 159

17.11 Minerals 160

17.12 Chemical Composition of Defective Coffee Beans 160 References 161

18. Polysaccharides in Coffee and Their Relationship to Health: An Overview CARMEN L. DE OLIVEIRA PETKOWICZ

18.1 Introduction 163

18.2 Green Coffee 163

18.3 Roasted Coffee 167

18.4 Health Aspects of Coffee Polysaccharides 169

18.5 Summary Points 171

References 171
19. Galactomannans in Coffee

ANA S.P. MOREIRA, FERNANDO M. NUNES, M. ROSÁRIO M. DOMINGUES, MANUEL A. COIMBRA

19.1 Introduction 173

19.2 Structural Features of Green Coffee Galactomannans 174

19.3 Effect of the Roasting Process on the Structure of Coffee Galactomannans 176

19.4 Potential Health Implications of Coffee Polysaccharides 178

19.5 The Effect of Galactomannans on Organoleptic Properties of Coffee Beverages 180

19.6 Summary Points 181 References 181

20. Melanoidins in Coffee JOSÉ A. RUFIÁN-HENARES, SILVIA PASTORIZA

20.1 Introduction 183

20.2 Chemical Composition 183

20.3 Mechanistic Formation and Structure of Coffee Melanoidins 185

20.4 Final Remarks 187

20.5 Summary Points 187

References 188

\section{Chlorogenic Acids from Coffee} YUSAKU NARITA, KUNIYO INOUYE

21.1 Introduction 189

21.2 CGAs in Green Coffee Beans 192

21.3 CGAs in Roasted Coffee Beans 192

21.4 CGAs in Defective Coffee Beans, Spent Coffee Grounds, and Coffee Silverskin 197

21.5 Summary Points 197 References 197

\section{Caffeine in Coffee FRANCISZEK BURDAN}

22.1 Introduction 201

22.2 Content of Caffeine in Coffee and in Nutritional and Medical Products 201

22.3 Caffeine Consumption 205

22.4 Pharmacokinetics of Caffeine 206

22.5 Summary Points 206

References 207

\section{Coffee and Hippuric Acid} MASANORI OGAWA

23.1 Introduction 209

23.2 Metabolism of CGA to HA 209

23.3 Elevation of HA in Human Studies 209

23.4 Variation of Colonic Microflora 210

23.5 Biological Properties of CGA and HA 210

23.6 Other Sources of HA 212 
23.7 Present Status in the Estimation of Toluene Exposure in the Occupational Field 213

23.8 Summary Points 213

References 214

24. Factors Affecting Acrylamide Levels in Coffee Beverages

CRISTINA M.D. SOARES, RITA C. ALVES, M. BEATRIZ P.P. OLIVEIRA

24.1 Introduction 217

24.2 Factors Affecting Acrylamide Levels in Coffee Beverages 217

24.3 Reduction of Acrylamide in Coffee Products 222

24.4 Conclusion 223

24.5 Summary Points 223

Acknowledgments 223

References 223

25. Mycotoxins in Coffee

TIAGO VIEIRA, SARA CUNHA, SUSANA CASAL

25.1 Introduction 225

25.2 What are Mycotoxins? 225

25.3 Major Mycotoxins in Coffee 226

25.4 Coffee Processing and Mycotoxin Contamination 229

25.5 Summary Points 231

Acknowledgments 231

References 231

\section{Pesticide Residues in Coffee} Agroecosystems

MARCELO RODRIGUES DOS REIS, FLÁVIO LEMES FERNANDES, EVERALDO ANTÔNIO LOPES, JÉSSICA EMILIANE RODRIGUES GORRI, FLÁVIA MARIA ALVES

26.1 Introduction 235

26.2 Pesticides (Fungicides, Herbicides, Insecticides, and Nematicides) 235

26.3 New Strategies for Reducing Pesticide Residues in Coffee 243

26.4 Summary Points 243

References 244

\section{Part 1.4 Coffee Types and Coffee Drinking Culture}

27. Physicochemical Characteristics of Roasted Coffee

XIUJU WANG, LOONG-TAK LIM

27.1 Introduction 247

27.2 Physical and Structural Characteristics of Roasted Coffee Beans 247

27.3 Chemical Composition 249

27.4 Summary Points 252

References 253
28. Espresso Machine and Coffee Composition SAURO VITTORI, GIOVANNI CAPRIOLI, MANUELA CORTESE, GIANNI SAGRATINI

28.1 Introduction 255

28.2 Espresso Coffee Machine: Working Principles 256

28.3 Influence of Water Temperature and Water Pressure on ECs Quality 257

28.4 Time Portions: Extraction Kinetic 259

28.5 Conclusions 262

28.6 Summary Points 263

References 263

29. Boiled Coffee: An Arctic Example of Potential Residual and Unmeasured Confounding in Coffee Epidemiology

LENA MARIA NILSSON

29.1 Introduction 265

29.2 Residual and Unmeasured Confounding in Coffee Epidemiology 265

29.3 Coffee: A Part of the Scandinavian Culture Since the 1700s 266

29.4 Chemical Implications of the Preparation of Boiled Coffee 267

29.5 Risk Associations in Boiled and Filtered Coffee 268

29.6 Lifestyle Factors Associated with Consumption of Boiled and Filtered Coffee 268

29.7 Discussion 272

29.8 Summary Points 273

References 273

30. Personality Traits and Coffee Intake DIOGO R. LARA

30.1 Introduction 275

30.2 Personality Traits Associated with Coffee and Caffeine Intake 276

30.3 Differential Response to Caffeine According to Personality Traits and Psychiatric Disorders 276

30.4 Chronic Use of Coffee, Personality Traits, and Psychiatric Disorders 277

30.5 Conclusions 278

30.6 Summary Points 278

References 279

\section{Part 1.5 By-Products and Secondary Usage}

31. An Overview of the Potential Uses for Coffee Husks

LEANDRO S. OLIVEIRA, ADRIANA S. FRANCA

31.1 Introduction 283

31.2 Coffee Processing 283 
31.3 Chemical Composition of CHs and CP 285

31.4 Review of Proposals for the Profitable Exploitation of $\mathrm{CHs}$ and CP 286

31.5 Concluding Remarks 290

31.6 Summary Points 290 Acknowledgments 290 References 290

32. Use of Coffee Husk Waste for Production of Biopesticides for Mosquito Control

SUBBIAH POOPATHI, C. MANI

32.1 Introduction 293

32.2 Method of Biopesticide Production from CHW 294

32.3 Salient Features of the Study 296

32.4 Conclusion 299

32.5 Summary Points 299

Acknowledgments 299

References 300

33. Production of Selenium-Enriched Mushrooms in Coffee Husks and Use of This Colonized Residue

MARIA CATARINA MEGUMI KASUYA, JOSÉ MARIA RODRIGUES DA LUZ, MATEUS DIAS NUNES, MARLIANE DE CÁSSIA SOARES DA SILVA, DANIELE RUELA DE CARVALHO, LAÉLIA SOARES DE ASSUNÇÃO, THIAGO DE ALMEIDA PAULA, CAROLINE MOURA, CLÁUDIA BRAGA PEREIRA BENTO

33.1 Introduction 301

33.2 Production of Different Types of Mushrooms 302

33.3 Enrichment of Mushrooms with Selenium 303

33.4 Potential Use of the Coffee Husk in Animal Feed after Fungal Colonization 305

33.5 Conclusions/Summary Points 307 Acknowledgments 308 References 308

34. Spent Coffee-Based Activated Carbons: Production, Properties, and Environmental Applications TERESA J. BANDOSZ, KARIFALA KANTE

34.1 Introduction 311

34.2 Preparation of Coffee-Based Activated Carbons and Their Surface Features 312

34.3 Applications as Adsorbents from Gas and Vapor Phases 314

34.4 Applications of Coffee-Derived Carbons as Adsorbents from Liquid Phase 314

34.5 Applications of Coffee-Derived Carbons as Supercapacitors 315

34.6 Summary Points 316

References 317
SECTION 2

EFFECTS OF COFFEE CONSUMPTION

\section{Part 2.1 Infection and Immunity}

35. Coffee Consumption and C-reactive Protein: Epidemiological Studies

NGOC M. PHAM, VICTOR R. PREEDY

35.1 Introduction 323

35.2 Epidemiological Evidence for the Relationship between Coffee and CRP 325

35.3 Interpreting and Analyzing the Data on the Relationship between Coffee and CRP 329

35.4 Conclusions 332

35.5 Summary Points 332

References 332

36. Effects of Coffee on Antigen-Specific Immune Responses In Vivo and In Vitro MASAO GOTO, YUKO TAKANO-ISHIKAWA

36.1 Introduction 335

36.2 Effects of Coffee Administration in a DO11.10 Allergic Mouse Model 336

36.3 Change in Antigen-Specific Proliferation of Splenocytes Caused by Drinking Coffee 340

36.4 Summary Points 341

References 342

37. Anti-Hepatitis C Virus Treatment and Coffee Drinking ALEXANDRE PARIENTE, RODOLPHE ANTY

37.1 Factual Associations 343

37.2 Coffee Drinking and Liver Lesions in Hepatitis C 343

37.3 Coffee Drinking and Response to Treatment with Peginterferon and Ribavirin 345

37.4 An Interventional Study of Coffee in Hepatitis C 346

37.5 Conclusion 346 References 346

\section{Part 2.2 Cancer}

38. Epidemiological Evidence on the Relation between Coffee Intake and the Risk of Head and Neck Cancer ALESSANDRA TAVANI, CARLOTTA GALEONE, FEDERICA TURATI, LODOVICA CAVALLI, CARLO LA VECCHIA

38.1 Introduction 349

38.2 Main Text 349 
38.3 Summary Points 357

Acknowledgments 357

References 357

39. Coffee Consumption and Prostate Cancer VAN DONG HOANG, VAN DINH TRAN, ANDY H. LEE

39.1 Introduction 359

39.2 Literature Search 360

39.3 Epidemiological Evidence (Before 2000) 360

39.4 Epidemiological Evidence (2001-Present) 363

39.5 Limitations 364

39.6 Conclusions and Future Perspectives 365

39.7 Summary Points 365

References 365

40. Coffee Intake and Pancreatic Cancer Risk JEANINE M. GENKINGER, VALERIE GEBARA

40.1 Introduction 367

40.2 Coffee Consumption and Carcinogenesis 367

40.3 Pancreatic Cancer Epidemiology 367

40.4 Pancreatic Cancer Risk Factors 368

40.5 Coffee Intake and Pancreatic Cancer Risk in Epidemiologic Studies 368

40.6 Summary 372

40.7 Summary Points 372

References 372

\section{Part 2.3 Cardiovascular}

41. Coffee and Risk of Cardiovascular Disease:

An Overview of Epidemiologic Studies ROMINA DI GIUSEPPE, JANINE WIRTH, CORNELIA WEIKERT

41.1 Introduction 377

41.2 Coffee and CHD Risk 377

41.3 Coffee and Stroke Risk 380

41.4 Coffee and Heart Failure Risk 382

41.5 Coffee and CVD Mortality 383

41.6 Concluding Remarks 383

41.7 Summary Points 384

Acknowledgments 384

References 384

42. Coffee Polyphenols and High Cardiovascular Risk

\section{Parameters}

ANNA TRESSERRA-RIMBAU, ALEXANDER MEDINA-REMÓN, RAMON ESTRUCH, ROSA M. LAMUELA-RAVENTÓS

42.1 Introduction 387

42.2 Coffee: An Important Source of

Polyphenols 387

42.3 Bioavailability of Coffee Polyphenols 388
42.4 In Vitro and Human Cell Studies 389

42.5 Animal Studies 390

42.6 Epidemiological Studies 390

42.7 Clinical Trials 391

42.8 Summary Points 393

References 393

43. Coffee and Hypertension: A Focus on Contrasting Acute and Chronic Effects and

Nutrigenetics

GIULIA RENDA, RAFFAELE DE CATERINA

43.1 Introduction 395

43.2 Acute Effects of Coffee on Blood Pressure 396

43.3 Effects of Coffee on the Long-term Risk of Hypertension 397

43.4 Nutrigenetics of Blood Pressure Responses to Coffee Drinking 399

43.5 Conclusions 400

43.6 Summary Points 400

References 401

44. Coffee Consumption and Risk of Venous Thromboembolism

KRISTIN F. ENGA, JOHN-BJARNE HANSEN

44.1 Clinical Presentation 403

44.2 Incidence and Complications 403

44.3 Pathogenesis and Risk Factors 403

44.4 Coffee Consumption and Risk of VTE 405

44.5 Underlying Protective Mechanisms of Coffee on Risk of VTE 406

44.6 Limitations of Findings on Behavioral Factors in Observational Studies 407

44.7 Conclusions 407

44.8 Summary Points 407

References 407

45. Coffee Consumption and Serum Lipids: A Review of Epidemiological Studies and Experimental Studies in Humans

DEFU MA, LI CAI, XIAOLONG HAN, PEIYU WANG

45.1 Introduction 409

45.2 Epidemiological Studies on Coffee Consumption and Serum Lipids 409

45.3 Experimental Studies on Coffee Consumption and Serum Lipids 410

45.4 Boiled Coffee and Filter Coffee 411

45.5 Caffeinated Coffee and Decaffeinated Coffee 418

45.6 Conclusions 419

45.7 Summary Points 419

References 419 


\section{Part 2.4 Nervous System and Behaviour}

46. Coffee and its Active Compounds are

Neuroprotective

JIYOUNG KIM, KI WON LEE

46.1 Introduction 423

46.2 Caffeine as a Neuroprotectant 423

46.3 Decaffeinated Coffee Is Neuroprotective 423

46.4 Neuroprotective Active Compounds in Coffee 424

46.5 Antioxidative Activities of Phytochemicals in Coffee 425

46.6 Anti-inflammatory Activities of Phytochemicals in Coffee 425

46.7 Conclusion 426

46.8 Summary Points 426

Acknowledgments 426

References 426

47. Coffee and Amyotrophic Lateral Sclerosis

GIORGIA GIUSSANI, ELISABETTA PUPILLO, PAOLO MESSINA, ETTORE BEGH

47.1 Introduction: The Disease 429

47.2 Coffee and ALS: The Epidemiological

Evidence 429

47.3 Molecular Targets of Caffeine in the Central Nervous System 431

47.4 Studies in Animal Models 431

47.5 Electrophysiological Effects of Caffeine 432

47.6 Caffeine and Other Neurodegenerative Disorders 432

47.7 Effects of Other Constituents of Coffee 433

47.8 Summary Points 433

References 433

48. Coffee, Granulocyte Colony-Stimulating Factor (G-CSF), and Neurodegenerative

Diseases

CHUANHAI CAO, THEA MOORE, LI CHU, OING XU

48.1 Background 435

48.2 Coffee, Caffeine, and AD and Parkinson's

Disease 437

48.3 Coffee and G-CSF 440

48.4 The Mechanism of Coffee Benefit in Neurodegenerative Disease 440

48.5 Conclusions 441

48.6 Summary Points 441

Acknowledgments 441

References 441
49. Coffee-Induced Neural Tube Defects

GIANFRANCO CARLOMAGNO, SARA DE GRAZIA, ALBERTO VAIARELLI, VITTORIO UNFER

49.1 Introduction 443

49.2 NTDs, Folic Acid, and Inositol 444

49.3 Caffeine Intake and NTDs 445

49.4 Summary Points 447

References 447

50. Coffee and Anxiety

CONCEPCIÓN VINADER-CAEROLS, SANTIAGO MONLEÓN, ANDRÉS PARRA

50.1 Introduction 449

50.2 What Is Anxiety? 449

50.3 Coffee and Normal Anxiety 450

50.4 Coffee and Pathological Anxiety 452

50.5 Conclusions 453

50.6 Summary Points 454

Acknowledgments 454

References 454

51. Coffee-Related Insomnia

JENNIFER COUSINS, IRIS R. BELL, RICHARD R. BOOTZIN

51.1 Introduction 457

References 463

\section{Part 2.5 Diabetes and Glucose Control}

52. Coffee Intake and Diabetes

TERESA H.M. DA COSTA, CAIO E.G. REIS, ADRIANA LOFRANO PORTO, ANGÉLICA AMATO, JOSÉ G. DOREA

52.1 Introduction 467

52.2 Prospective Longitudinal Cohort Studies of Coffee and Type 2 Diabetes 467

52.3 Cross-sectional Studies of Coffee and Type 2 Diabetes 474

52.4 Summary Points 477

References 477

53. The Influence of Acute Caffeine and Coffee Consumption on Glucose Homeostasis: Whole-Body and Tissue-Specific Effects and Mechanisms of Actions MARIE-SOLEIL BEAUDOIN, TERRY E. GRAHAM

53.1 Introduction 479

53.2 Acute Effects of Alkaloid Caffeine on Glucose Homeostasis 479 
53.3 Acute Effects of Caffeinated Coffee on Carbohydrate Homeostasis 481

53.4 Considerations in Caffeine/Coffee-Induced Insulin Resistance 484

53.5 Proposed Mechanisms of Action for Caffeine 484

53.6 Conclusion 487

53.7 Summary Points 488

References 488

\section{Part 2.6 Metabolism and Other Organ Systems}

54. Coffee Consumption and Neglected Risk-Benefits on Health and Disease

ELENA ALONZO, FRANCESCA M. TROVATO, DANIELA CATALANO, GUGLIELMO M. TROVATO

54.1 Introduction 493

54.2 Surgical and Anesthesia-Related

Conditions 493

54.3 Pregnancy, Fertility, and Sexual-Related Ailments 494

54.4 Menopause 494

54.5 Childbearing and Infancy 495

54.6 Infectious Disease 495

54.7 Respiratory Disease (Asthma and COPD) 495

54.8 Dentistry 495

54.9 Occupational Disease 495

54.10 Conclusions 495

54.11 Summary Points 495

References 496

55. Coffee Consumption and Body Weight

Regulation

MARIE-PIERRE ST-ONGE

55.1 Introduction 499

55.2 Epidemiological Evidence Linking Coffee Consumption and Weight Status 499

55.3 Impact of Coffee and Caffeine on EE 501

55.4 Effects of Coffee Consumption on Appetite Regulation 502

55.5 Effects of Coffee Consumption in Weight Loss 503

55.6 Summary Points 505

References 505

56. Coffee Consumption and Adiponectin: An Overview of Epidemiological Studies

\section{TAKUYA IMATOH}

56.1 Introduction 507

56.2 Adiponectin 508

56.3 Published Epidemiological Studies on Association between Coffee Consumption and Adiponectin Level 510

56.4 Potential Mechanisms that Increase the Levels of Adiponectin 510
56.5 Which Coffee Components Play an Important Role on Increasing Adiponectin Levels? 512

56.6 Discussion 513

56.7 Summary Points 514

References 514

57. Effect of Coffee Consumption on Oral Health

FLÁVIO HENRIQUE BAGGIO AGUIAR, NÚBIA PAVESI PINI, DÉBORA ALVES NUNES LEITE LIMA, JOSÉ ROBERTO LOVADINO

57.1 Introduction 517

57.2 Review of Literature 517

57.3 Summary and Conclusions 520

57.4 Summary Points 520

References 520

58. Role of Coffea arabica Extract and Related Compounds in Preventing Photoaging and Photodamage of the Skin

HSIU-MEI CHIANG, CHIEN-WEN CHEN, CHIEN-CHIA CHEN, HSIAO-WEN WANG, JHE-HUA JHANG, YA-HAN HUANG, KUO-CHING WEN

58.1 Introduction 523

58.2 Aging and Photoaging 523

58.3 Mechanisms of Photoaging 524

58.4 Antioxidant Activity of Coffee 525

58.5 Coffee Prevents Skin Photoaging 525

58.6 Coffee Prevents Skin Tumor Formation 526

58.7 Effect of Coffee Constituents on Photoaging and Photocarcinogenesis 526

58.8 Conclusion 529

58.9 Summary Points 529

References 529

59. Coffee and Renal Function and Disease DANIELA CATALANO, FRANCESCA M. TROVATO, FABIO MARTINES, GUGLIELMO M. TROVATO

59.1 Introduction 531

59.2 Conclusion 534

References 534

60. Coffee and Gastrointestinal Glucuronosyltransferases CHRISTIAN P. STRASSBURG, SANDRA KALTHOFF

60.1 Introduction 535

60.2 UDP-Glucuronosyltransferases 535

60.3 Glucuronidation of Hydroxycinnamic Acids 537

60.4 Coffee-Mediated UGT1A Regulation in Cell Culture 537

60.5 Coffee-Mediated UGT1A Activation in Mouse Models 539

60.6 Contribution of UGTs to the Coffee-Mediated Protective Effects on the Metabolism and Genotoxicity of the Dietary Carcinogen PhIP 540

60.7 Summary Points 542 References 542 
61. Effects of Coffee on Estrogen Sulfation in Human Colon Carcinoma Caco-2 Cells HIROOMI TAMURA

61.1 Introduction 545

61.2 Coffee Inhibits Sulfation of Estradiol in Caco-2 Cells 546

61.3 Characterization of the Inhibitory Activity in Coffee Toward $E_{2}$ Sulfation in Caco-2 Cells 546

61.4 Effects of Coffee on the Expression of SULT1E1 547

61.5 Effects of Coffee on STS and BCRP 547

61.6 Characterization of the Active Constituents that Regulate the Expression of the Estrogen SulfationRelated Genes SULT1E1, STS, and BCRP 549

61.7 Conclusion 551

61.8 Summary Points 551

Acknowledgments 551

References 551

62. Coffee and the Liver: An Overview of Epidemiologic Studies RODOLPHE ANTY, ALEXANDRE PARIENTE

62.1 Summary Points 553

62.2 The Limits of Epidemiological Studies 553

62.3 Coffee and Liver Enzymes 554

62.4 Coffee, Cirrhosis, and Liver Fibrosis 554

62.5 Coffee, NAFLD, and NASH 556

62.6 Coffee and Hepatocellular Carcinoma 556

62.7 Putative Mechanisms of Action of Coffee on the Liver 557

62.8 Conclusions 557

Acknowledgment 557

References 557

63. Organic and Conventional Arabica Coffee L: Protective Effects on Liver Under Pre-neoplastic Conditions

CRISTIANA SCHMIDT DE MAGALHÃES, LUCIANA AZEVEDO, JESSICA EMI TAKARADA, NATHÁLIA CARVALHO COSTA, DAYENE DO CARMO CARVALHO

63.1 Introduction 559

63.2 Differentiation in Coffee Production System 560

63.3 Coffee Compounds 561

63.4 Liver Neoplasia 562

63.5 Coffee: Bioprotector Effect in Liver Neoplasia 562

63.6 Conclusion 565

63.7 Summary Points 565

References 565

64. Coffee and Prevention of Nonalcoholic Fatty Liver Disease

FRANCESCA M. TROVATO, DANIELA CATALANO, GIUSEPPE F. MARTINES, GUGLIELMO M. TROVATO

64.1 Introduction 567

64.2 Coffee and NAFLD 568
64.3 Summary Points 572

References 572

65. Estimate of Acrylamide Intake from Coffee and Health Risk Assessment ADRIANA PAVESI ARISSETO, EDUARDO VICENTE

65.1 Introduction 575

65.2 Toxicological Aspects of Acrylamide 576

65.3 Exposure Assessment to Acrylamide from Coffee 577

65.4 Health Risk Assessment 581

65.5 Cancer Evidence from Epidemiological Studies 582

65.6 Considerations about Risk Management

Actions 582

65.7 Conclusions 582

65.8 Summary Points 583

References 583

\section{Part 2.7 Cellular and Molecular Biology}

66. Protective Effects of Coffee Against Induction of DNA Damage and Cancer by Aflatoxin $B_{1}$

FRANZISKA FERK, KARL SPEER, MIROSLAV MIŠÍK, ARMEN NERSESYAN, SIEGFRIED KNASMÜLLER

66.1 Introduction 587

66.2 Occurrence of Aflatoxins in Foods and Human Cancer

Risks Caused by Consumption of Contaminated

Foods 587

66.3 Metabolism and Detoxification of $\mathrm{AFB}_{1} \quad 588$

66.4 Prevention of DNA Damage and Inhibition of Preneoplastic Lesions 588

66.5 Prevention of DNA Damage by Different Constituents of Coffee 588

66.6 Molecular Mechanisms 591

66.7 Does Coffee Protect Humans against Aflatoxin $B_{1}$ ? 593

66.8 Summary Points 594

References 594

67. Instant Coffee and Protection against DNA

Damage

TAKESHI HIRANO, HARUKI MORII, TAMIJI NAKASHIMA

67.1 Introduction 597

67.2 Coffee Consumption and Cancer 597

67.3 8-Oxoguanine 598

67.4 8-Oxoguanine Repair System 599

67.5 Instant Coffee Consumption and 8-Oxoguanine Generation and Repair 599

67.6 Conclusions 601

67.7 Summary Points 601

Acknowledgments 601

References 601 


\section{SECTION 3}

\section{EFFECTS OF SPECIFIC COMPOUNDS FOUND IN COFFEE}

\section{Part 3.1 Infection and Immunity}

68. Anti-Hepatitis B Virus Activity of Chlorogenic Acid and Its Related Compounds JIANPING ZUO, WEI TANG, YIBIN XU

68.1 Anti-Hepatitis B Virus Activity of Chlorogenic Acid and Its Related Compounds 607

68.2 Chlorogenic Acid Possesses Potent Anti-HBV Activity 608

68.3 Anti-HBV Activity of Chlorogenic Acid-Related Compounds 609

68.4 Hybrids of Caudatin and Chlorogenic Acid 610

68.5 Summary Points 612

References 612

69. Coffea canephora: A Promising Natural Anticariogenic Product

DANIEL COHEN GOLDEMBERG, ANDREA GONÇALVES ANTONIO, ADRIANA FARAH, LUCIANNE COPLE MAIA

69.1 Introduction 615

69.2 Coffea canephora 616

69.3 Dental Caries Pathogenesis and the Protective Role of Coffee: A Focus on C. canephora Species 617

69.4 Conclusions 623

69.5 Summary Points 624

Acknowledgments 624

References 624

70. Kahweol, a Coffee Diterpene with Anti-inflammatory Properties

CASIMIRO CÁRDENAS, ANA R. QUESADA, MIGUEL Á. MEDINA

70.1 Introduction 627

70.2 Kahweol Modulates Nitric Oxide Synthesis 627

70.3 Kahweol Modulates Cyclooxygenase-2 Expression 628

70.4 Kahweol Modulates Cell Adhesion 629

70.5 Kahweol Protects against Oxidative Stress and DNA Damage 629

70.6 Kahweol Targets NF-кB/STAT-1-Mediated Inflammatory Responses 630

70.7 Kahweol Targets MCP-1 Secretion in Endothelial Cells 630

70.8 Kahweol Behaves as an Anti-Angiogenic Agent 630

70.9 Concluding Remarks 631

70.10 Summary Points 632

References 632
71. Antifungal Inhibitory Activities of Caffeic and Quinic Acid Derivatives

JAN-NAN MA, CHAO-MEI MA

71.1 Introduction 635

71.2 Caffeoylquinic, Caffeic, and Quinic Acid Derivatives with Antifungal Activity 637

71.3 Summary Points 640 Acknowledgment 641 References 641

\section{Part 3.2 Cancer}

72. On the Linkage between Caffeine, Cytokine Secretion, and Cancer

MEIR DJALDETTI, MICHAEL BERGMAN, HERTZEL SALMAN, HANNA BESSLER

72.1 Introduction 645

72.2 Caffeine, Cytokine Secretion, and Cancer 645

72.3 Summary Points 652

References 652

73. Anticancer Effect of Caffeic Acid on Human Cervical Cancer Cells

G. KANIMOZHI, N.R. PRASAD

73.1 Introduction 655

73.2 Caffeic Acid on Cancer Cell Proliferation 656

73.3 Caffeic Acid on Intracellular ROS Level, Mitochondrial Membrane Potential, and Apoptosis 656

73.4 Changes in the Levels of Lipid Peroxidative and the Activities of Enzymatic Antioxidants 658

References 660

74. Caffeic and Ferulic Acid Derivatives: Use in Breast Cancer

TERESA L. SERAFIM, NUNO MILHAZES, FERNANDA BORGES, PAULO J. OLIVEIRA

74.1 Introduction: Coffee Consumption and Breast Cancer 663

74.2 Caffeic and Ferulic Acid Antibreast Cancer Activity 665

74.3 Summary Points 669

References 670

75. Molecular Targets of Coffee Phytochemicals Caffeic Acid and Chlorogenic Acid in

Chemoprevention ANN M. BODE, ZIGANG DONG

75.1 Introduction 673

75.2 Antioxidant Activity of Coffee and Its Components 674

75.3 Strategies for Identifying Molecular Targets of Coffee Components 676

75.4 Summary Points 678

References 678 


\section{Part 3.3 Cardiovascular}

76. Caffeine and SPECT Myocardial Perfusion Imaging

FURQAN H. TEJANI, SARITA KONKA

76.1 Introduction 683

76.2 Coronary Artery Disease 683

76.3 TIMI Risk Score 683

76.4 Myocardial Ischemia 683

76.5 Principle of Cardiac Stress Testing 684

76.6 Types of Cardiac Stress Tests 684

76.7 Sensitivity/Specificity of Cardiac Stress Testing 684

76.8 Effects of Caffeine on Stress Testing 684

76.9 Current Guidelines Regarding Caffeine and Stress Testing 688

76.10 Topics to Consider and Future Investigations 688

76.11 Summary Points 688

References 688

\section{Caffeine and Atrial Fibrillation ANNA VITTORIA MATTIOLI}

77.1 Introduction 691

77.2 Pathophysiological Link between Caffeine and Arrhythmias 691

77.3 Human Studies 693

77.4 Energy Drinks and Caffeine 695

77.5 Conclusions 697

77.6 Summary Points 697

References 697

78. Caffeine Cardiovascular Toxicity: Too Much of a Good Thing CLÁUDIA DEUS, ANA F. BRANCO, PAULO J. OLIVEIRA, VILMA SARDÃO

78.1 Introduction 699

78.2 Caffeine and the Heart 699

78.3 Summary Points 706

References 707

79. Potential Effects of Chlorogenic Acids on Platelet Activation

JAE B. PARK

79.1 Introduction 709

79.2 Coffee and Its Chemicals 709

79.3 Chemical Properties, Absorption, and Metabolism of CHAs 710

79.4 Bioavailability of Chlorogenic Acids 711

79.5 Cardiovascular Disease and Chlorogenic Acids 712

79.6 Effects of Chlorogenic Acids on ROS 713

79.7 Effects of Chlorogenic Acids on COX-I and II Enzymes 714

79.8 Effects of Chlorogenic Acids on P-Selectin 714

79.9 Conclusion 715

References 715

\section{Part 3.4 Nervous System and Behaviour}

80. Use of Caffeine for Cognitive Enhancement ANDREAS G. FRANKE, CHRISTIANA BAGUSAT

80.1 Introduction 721

80.2 Mechanism of Action 722

80.3 Cognitive-Enhancing Effects and Side Effects of Caffeine 723

80.4 Epidemiology of the Use of Caffeine for CE 724

80.5 Conclusions 726

80.6 Summary Points 726

References 726

81. Caffeolyquinic Acid Protects against Alzheimer's Disease through Inhibition of Amyloid Beta-Induced Toxicity

JUNKYU HAN, ABDELFATTEH EL OMRI, KAZUNORI SASAKI, HIROKO ISODA

81.1 Introduction 729

81.2 Caffeolyquinic Acid 729

81.3 Amyloid $\beta 731$

81.4 Neuroprotective Effect of CQA 731

81.5 Protective Effect on the Aggregation of $A \beta 732$

81.6 Conclusion 733

81.7 Summary Points 733

References 734

82. Neuroactive $\beta$-Carbolines Norharman and Harman in Coffee SUSANA CASAL

82.1 Introduction 737

82.2 Norharman and Harman: The Molecules 737

82.3 Norharman and Harman Health Impact 738

82.4 Norharman and Harman in Coffee 740

82.5 Summary Points 742

References 742

\section{Part 3.5 Diabetes and Glucose Control}

\section{Caffeine, Insulin Resistance,} and Hypertension

MARIA PEDRO GUARINO, JOANA SACRAMENTO, MARIA JOÃO RIBEIRO, SÍLVIA VILARES CONDE

83.1 Caffeine and the Metabolic Syndrome 747

83.2 Caffeine-Pharmacology and Mechanisms of Action 748

83.3 Effect of Caffeine on Insulin Action 749

83.4 Caffeine and Hypertension 750

83.5 Chronic Caffeine Administration in the Prevention and Reversion of Diet-Induced Insulin Resistance and Hypertension 751 
83.6 The Carotid Body as a Pharmacological Target for Caffeine 753

83.7 Summary Points 753

References 754

84. Inhibition of Porcine Pancreas $\alpha$-Amylase by Chlorogenic Acids from Green Coffee Beans and Cinnamic Acid Derivatives: A Focus on Kinetic YUSAKU NARITA, KUNIYO INOUYE

84.1 Introduction 757

84.2 PPA Inhibitory Effects of 5-CQA, CA, and QA 758

84.3 PPA Inhibition by Eight Types of CGAs and Cinnamate Derivatives 761

84.4 Summary Points 762

References 762

85. Antidiabetic Effects of Trigonelline: Comparison with Nicotinic Acid

ORIE YOSHINARI, KIHARU IGARASHI

85.1 Introduction 765

85.2 The Effects of TRG and NA on T2DM Using GotoKakizaki Rats as a Nonobese Animal Model 766

85.3 How Does TRG Ameliorates Oxidative Stress in GK Rats? 766

85.4 The Antidiabetic Effect of TRG and NA on T2DM

Using KK-Ay Mice as an Obese Animal Model 769

85.5 Summary 773

85.6 Summary Points 774

References 774

86. Chlorogenic Acid in Whole Body and Tissue-Specific Glucose Regulation JASMINE M. TUNNICLIFFE, THERESA COWAN, JANE SHEARER

86.1 Introduction 777

86.2 Chlorogenic Acid 777

86.3 Content in Coffee 778

86.4 Chlorogenic Acid Absorption 778

86.5 CGA in Blood Glucose Management 779

86.6 Summary Points 783

References 784

\section{Part 3.6 Metabolism and Other Organ Systems}

87. Bioavailability and Metabolism of Chlorogenic Acids from Coffee

ADRIANA FARAH, GISELLE DUARTE

87.1 Introduction 789

87.2 CGA Content in Green Coffee 791

87.3 CGA in Ground Roasted and Brewed Coffees and Human Daily Intake 791
87.4 Bioavailability and Metabolism of CGA from Coffee 792

87.5 Interaction between CGA and Other Food Components 799

87.6 Concluding Remarks 800

87.7 Summary Points 800

References 800

88. Inhibitory Effects of Caffeic Acid on Free-Radical Formation HIDEO IWAHASHI

88.1 Introduction 803

88.2 Summary Points 810

References 810

89. Effects of Caffeic, Ferulic, and p-Coumaric Acids on Lipid Membranes NATAŠA POKLAR ULRIH

89.1 Introduction 813

89.2 Interactions of Hydroxycinnamic Acids with Model Lipid Membranes 814

89.3 Effects of Phenolic Acids on the Rigidity of Model Membranes in the Liquid-Disordered State 814

89.4 Effects of Phenolic Acids on the Rigidity of Model Membranes in the Gel Crystalline State 814

89.5 Correlation between Phenolic-Acid Polarity and Influence on the Properties of Model Lipid Membranes 815

89.6 Caco-2 Cell Permeation 817

89.7 Transcellular Permeability Model 817

89.8 Facilitated Mechanisms of Transport of Phenolic Acids through the Colon Epithelium 818

89.9 Interactions of p-Coumaric Acid with Lysosomes 818 89.10 The Blood-Brain Barrier 819

89.11 Summary Points 819

References 820

90. Pharmacology of Caffeine: The Main Active Compound of Coffee FRANCISZEK BURDAN

90.1 Introduction 823

90.2 Pharmacokinetics of Caffeine 823

90.3 Pharmacodynamics of Caffeine 827

90.4 Summary Points 828

References 828

91. Adenosine Receptors as the Biochemical Target for Low Doses of Caffeine B.B. FREDHOLM

91.1 Introduction 831

91.2 Caffeine Levels and Antagonism of Adenosine Receptors 831

91.3 Adenosine Levels and Activation of Adenosine Receptors 832 
91.4 Validation of Adenosine Receptors as a Major Caffeine Target 833

91.5 Summary Points 833

References 833

92. Antioxidant Activity of Caffeine: A Focus on Human Red Blood Cells and Correlations with Several Neurodegenerative Disorders ESTER TELLONE, ANTONIO GALTIERI, BRUNO GIARDINA, ANNAMARIA RUSSO, ERSILIA BELLOCCO, DAVIDE BARRECA, SILVANA FICARRA

92.1 Introduction 835

92.2 Oxygen and Its Toxicity 835

92.3 Antioxidant Effects of Caffeine 836

92.4 Summary Points 841

References 841

93. Antioxidant Properties of Hydroxycinnamic Acid Derivatives: A Focus on Biochemistry, Physicochemical Parameters, Reactive Species, and Biomolecular Interactions HELENA ABRAMOVIČ

93.1 Introduction 843

93.2 Efficiency of HCs to Scavenge Reactive Nitrogen or Oxygen Species 845

93.3 Effect of HCs on the Oxidation of Biomolecules 847

93.4 Summary Points 850

References 851

94. Biological Effects of Coffee Melanoidins JOSÉ A. RUFIÁN-HENARES, SILVIA PASTORIZA

94.1 Introduction 853

94.2 Role of Coffee Melanoidins as Modulators of the Gut Microbiota 854

94.3 Coffee Melanoidins as Antimicrobial Agents 854

94.4 The Antioxidant Activity of Coffee Melanoidins 855

94.5 The Chelating Activity of Coffee Melanoidins 856

94.6 Coffee Melanoidins as Enzymes Modulators 856

94.7 Final Remarks 857

94.8 Summary Points 857 References 858

95. Melanoidins from Coffee and Lipid Peroxidation DAVIDE TAGLIAZUCCHI

95.1 Introduction 859

95.2 Lipid Peroxidation and Diseases 859

95.3 Sources of Dietary Lipid Oxidation Products and ALEs 860

95.4 Coffee Melanoidins: Structure and Biological Activity 861

95.5 Coffee Melanoidins As Radical Scavengers, Metal Chelators, and Lipid Peroxidation Inhibitors 861

95.6 Coffee Melanoidins Inhibit Lipid Peroxidation during Simulated Digestion of Meat 864

95.7 In vivo Evidence of Coffee Melanoidins As Inhibitors of Lipid Peroxidation 865
95.8 Conclusion 866

95.9 Summary Points 866

References 866

96. Coffee and Bone Metabolism: Kahweol and Osteoclastogenesis

EIKO SAKAI, TAKAYUKI TSUKUBA

96.1 Introduction 869

96.2 Kahweol Suppresses OCL Differentiation but Not Cell Viability 870

96.3 Kahweol Has Inhibitory Effects on Intracellular Signaling in OCLs 871

96.4 Kahweol Inhibits the Expression of OCL-Marker Proteins 871

96.5 Kahweol Induces mRNA Expression of Phase II Antioxidative Enzymes in OCLs 872

96.6 Kahweol Enhances HO-1 Protein Expression and Inhibits High Mobility Group Box 1

Release 872

96.7 Conclusion and Perspective 873

96.8 Summary Points 874

References 874

97. The Chemistry of Coffee Furans and Hydroxycinnamates under Simulated Gastric Conditions: Implications for Bioactivity and Bioavailability

ALESSANDRA NAPOLITANO, LUCIA PANZELLA

97.1 Modeling Gastric Conditions 877

97.2 The Acid-Mediated Chemistry of Nitrite in the Stomach 878

97.3 The Role of Thiocyanate and Other Saliva Ingredients 878

97.4 Reactivity of Hydroxycinnamic Acids and Their Esters Toward Acidic Nitrite 878

97.5 Purification and Differential Reaction Behavior of the Furan Diterpenes Cafestol and Kahweol Toward Nitrosating Agents 880

97.6 Implications for the Bioactivity and Bioavailability 883

97.7 Toxicological Implications of the Nitrite-Modified Molecules 884

97.8 Conclusions and Perspectives 884

97.9 Summary Points 885

References 885

98. Furan in Coffee Products: A Probabilistic Exposure Estimation DIRK W. LACHENMEIER

98.1 Introduction 887

98.2 Content of Furan in Coffee 887

98.3 Exposure Estimation 889

98.4 Risk Assessment of Furan in Coffee Products 891

98.5 Summary Points 892

Acknowledgment 892

References 892 


\section{Part 3.7 Cellular and Molecular Biology}

99. Caffeolyquinic Acid Induces the Upregulation of Glycolytic Enzymes

JUNKYU HAN, KAZUNORI SASAKI, ABDELFATTEH EL OMRI, HIROKO ISODA

99.1 Introduction 897

99.2 The Glycolytic and Nonglycolytic Functions of Glycolysis Enzymes 898

99.3 Relationship between Glycolytic Enzymes and Alzheimer's Disease 898

99.4 Metabolomics 899

99.5 Conclusion 900

99.6 Summary Points 900

References 903

100. Caffeic Acid and Organic Anion Transporters hOAT1 and hOAT3 YUICHI UWAI

100.1 Introduction 905

100.2 Renal Tubular Secretion of Drugs by OATs 906

100.3 Methotrexate-NSAID Interaction, as an Example of a Drug-Drug Interaction at OAT1 and OAT3 907

100.4 Inhibitory Effects of Caffeic Acid on Drug Transport by hOAT1 and hOAT3 908

100.5 Discussion of Interaction between Coffee and Substrates of hOAT1 and/or hOAT3 910

100.6 Summary Points 910

References 911

101. The Cytoprotective Effects of Hydroxycinnamic Acid are Mediated by Its Antioxidant Activity SEONG-GENE LEE

101.1 Introduction 913

101.2 Antioxidant Activity of HCAs 914

101.3 Anti-Inflammatory Activity of HCAs 915

101.4 Anti-Apoptotic Effects of HCAs 917

101.5 Metabolism of HCAs in Coffee 918

101.6 Summary Points 919

Acknowledgments 919

References 919

102. Cytoprotective Effect of Coffee Melanoidins LUIS GOYA, SONIA RAMOS, MARIA ANGELES MARTÍN, FRANCISCO J. MORALES

102.1 Introduction 921

102.2 A Cell Culture Model for the Assessment of the Chemopreventive Potential of Dietary Compounds 923

102.3 Coffee Melanoidins Protect HepG2 Cells against Oxidative Stress Induced by t-BOOH 925

102.4 Conclusion 927

102.5 Summary Points 927

Acknowledgments 928

References 928

\section{SECTION 4}

ANALYSIS AND METHODS

103. Use of Near-Infrared Spectroscopy for Coffee Beans Quality Assessment

RICARDO N.M.J. PÁSCOA, MAFALDA C. SARRAGUÇA, LUÍS M. MAGALHÃES, JOÃO R. SANTOS, ANTÓNIO O.S.S. RANGEL, JOÃO A. LOPES

103.1 Introduction 933

103.2 Summary Points 941

References 941

104. Spectroscopic Methods for Chemometric Identification of Defective and Nondefective Coffees ADRIANA S. FRANCA, LEANDRO S. OLIVEIRA

104.1 Introduction 943

104.2 Brief Overview of Spectroscopic Methods 944

104.3 Brief Overview of Chemometrics 945

104.4 Spectroscopic Methods in Green Coffee Analysis 946

104.5 Spectroscopic Methods in Roasted Coffee Analysis 947

104.6 Concluding Remarks 950

104.7 Summary Points 950

Acknowledgments 950

References 951

105. Overview of Currently Applied Techniques for Detection of Adulterants in Coffee and Potential Use of DNA-Based Methods as Promising New Analytical Tools

EDNA MARIA MORAIS OLIVEIRA, ADRIANA FARAH, OTNIEL FREITAS-SILVA, ANDRESSA MOREIRA DE SOUZA, THIAGO FERREIRA DOS SANTOS, MANUELA CRISTINA P. DE A. SANTIAGO

105.1 Introduction 953

105.2 Microscopic Methods 954

105.3 Spectroscopic Methods 955

105.4 Chromatographic Methods 955

105.5 DNA-Based Methods 957

105.6 Final Considerations 958

105.7 Summary Points 959

References 960

106. Assay of Total Antioxidant Capacity of Coffee: Use of a DNA-Based Biosensor

DIANA CRUZ, M. FÁTIMA BARROSO, RITA C. ALVES, MARÍA BEGOÑA GONZÁLEZ-GARCÍA, MARIA JOÃO RAMALHOSA, ABEL J. DUARTE, M. BEATRIZ P.P. OLIVEIRA, CRISTINA DELERUE-MATOS

106.1 Introduction 963

106.2 Sensors for the TAC Evaluation of Coffee Samples 964

106.3 DNA-Based Biosensors for TAC Assessment 965

106.4 Conclusions 969

106.5 Summary Points 969

Acknowledgments 969

References 969 
107. Determination of Polyphenols and Major Purine Alkaloids in Coffee: An Overview VICTORIA F. SAMANIDOU

107.1 Introduction 971

107.2 Analytical Methods 972

107.3 Chromatographic Techniques 974

107.4 Other Techniques 977

107.5 Conclusions 980

107.6 Summary Points 980

References 980

108. Determination of Caffeine in Coffee Using Low-Pressure Chromatography JOÃO RODRIGO SANTOS, ANTÓNIO O.S.S. RANGEL

108.1 Introduction 983

108.2 Analytical Methods for Determining Caffeine in Coffee 984

108.3 Determining Caffeine in Coffee Using a Low-Pressure Chromatographic Flow Injection System 986

108.4 Summary Points 989

Acknowledgments 990

References 990

109. Assay of Kahweol and Cafestol in Coffee MARTA DE TOLEDO BENASSI, RAFAEL CARLOS ELOY DIAS

109.1 Introduction 993

109.2 Sample Preparation and Extraction Methods 994

109.3 Separation, Identification, and Quantification of Diterpenes 995

109.4 Occurrence of Kahweol and Cafestol in Different Coffea Matrices 998

109.5 Summary Points 1003

References 1003
110. Analysis of Furan in Coffee MARTA MESIAS, FRANCISCO J. MORALES

110.1 Introduction 1005

110.2 Analysis of Furan in Food 1005

110.3 Furan in Coffee 1007

110.4 Summary Points 1011

References 1011

111. Analysis of Acrylamide in Coffee FRANCISCO J. MORALES, MARTA MESIAS

111.1 Introduction 1013

111.2 Methods of Analysis for Acrylamide 1014

111.3 Occurence of Acrylamide in Coffee 1017

111.4 Summary Points 1020

References 1020

112. Analysis of the Mycotoxin Ochratoxin A in Coffee

TIAGO VIEIRA, SARA CUNHA, SUSANA CASAL

112.1 Introduction 1023

112.2 Ochratoxin A 1023

112.3 Sampling and Sample Preparation 1024

112.4 Extraction 1025

112.5 Clean-up 1025

112.6 Detection and Quantification 1026

112.7 Confirmation 1028

112.8 Summary Points 1030

References 1030

\section{Index 1033}




\title{
Analysis of Acrylamide in Coffee
}

\author{
Francisco J. Morales, Marta Mesias
}

\section{Department of Characterisation, Quality and Safety, Institute of Food Science, Technology and Nutrition (ICTAN- CSIC), Spanish National Research Council, Madrid, Spain}

\section{List of Abbreviations}

APCI Atmospheric pressure chemical ionization

ASE Accelerated solvent extraction

CIAA Confederation of the European Food and Drink Industries

ESI Electrospray ionization

FDA Food and Drug Administration

FDE Food Drink Europe

GC Gas chromatography

GC-ECD Gas chromatography-electron capture detector

GC-MS Gas chromatography-mass spectrometry

HPLC High-performance liquid chromatography

HPLC-MS High-performance liquid chromatography-mass spectrometry

IRMM Institute of Reference Materials and Measurements

LC-MS Liquid chromatography-mass spectrometry

MAX Mixed-mode anion exchange

MCX Mixed-mode cation exchange

MIP Molecularly imprinted polymers

MISPE Molecularly imprinted solid-phase extraction

MRM Multiple reaction monitoring mode

MS Mass spectrometry

Quechers Quick, easy, cheap, effective, rugged, and safe

SFE Supercritical fluid extraction

SIM Single-ion monitoring mode

SPE Solid-phase extraction

3-APA 3-aminopropionamide

\subsection{INTRODUCTION}

For decades, potential sources of acrylamide exposure to the population have been drinking water treated with polyacrylamide in a refining process, as a part of accidental inhalation in working areas, smoking cigarettes, using certain cosmetics or from foodpackaging material. Since polyacrylamide contains up to $0.1 \%$ free acrylamide monomer, low amounts of acrylamide might migrate from food packaging material into the packed foodstuff. ${ }^{1}$ However, the specific migration limit for acrylamide from materials that come into contact with foodstuffs was defined as undetectable, with a limit of detection of $10 \mathrm{mg} / \mathrm{kg}$. ${ }^{2}$
In order to minimize the risk for the general population, a maximum tolerable level of $0.1 \mathrm{mg}$ acrylamide/1 drinkable water has been established within the European Union. ${ }^{3}$ However, in April 2002 the Swedish State Agency on Food and researchers from Stockholm University reported that large amounts of acrylamide were found in certain thermally processed starchy foods. ${ }^{4,5}$ The main chemical and physical features of acrylamide monomer are described in Figure 111.1. Acrylamide exerts genotoxic with mutagenic and carcinogenic activities in multiple organs in animals since it causes gene mutations and changes in chromosomes, and reproductive toxicity has also been described. ${ }^{6,7}$ Acrylamide is biotransformed in vivo to its epoxide, glycidamide $\left(\mathrm{C}_{3} \mathrm{H}_{5} \mathrm{NO}_{2}\right.$; CAS RN 5694-00-8), which is genotoxic in a variety of in vitro and in vivo test systems. In humans, increasing incidences of endometrial, ovarian, and renal cancer (but not brain cancer) with increased dietary acrylamide intake have been reported ${ }^{8}$

Taking together the information about acrylamide occurrence in foods and the previous knowledge of its harmful effect on human health was the statement of the Joint Expert Committee of FAO/WHO on Food Additives (JECFA) revealing that the toxicological threat caused by intake of acrylamide cannot be excluded. ${ }^{9}$ In July 2014, the European Food Safety Authority (EFSA) confirmed that dietary intake of acrylamide may increase the risk of developing cancer for consumers.

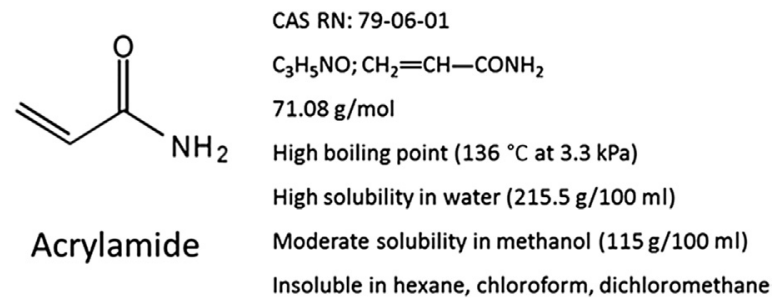

FIGURE 111.1 Chemical and physical properties of acrylamide monomer. 


\subsection{METHODS OF ANALYSIS FOR ACRYLAMIDE}

In this scenario of risk evaluation, advanced methods for acrylamide quantification are mandatory to accurately assess the human exposure to this harmful compound, and particularly to coffee. It is obvious that to obtain accurate and reproducible results, sample collection and preparation before instrumental analysis must be conducted with sufficient precision. On the other hand, there has been considerable interest in developing a rapid, sensitive, and accurate method for determining acrylamide in food products, a part of cost-effective methods.

Since 2002, many analytical methods have been developed and subsequently improved in time. There are several comprehensive reviews published on the numerous methods for acrylamide detection to date. ${ }^{10,11}$ However, an official method of acrylamide quantification in food has not yet been recommended. Efforts on standardization of methods used to detect and quantify acrylamide in foods have continued. A draft for an official method of acrylamide in foods has already been established by the European Committee of Normalization (Comité Europeén de Normalisation, CEN) under a specific European Commission mandate M/463 dated April 30, 2010. Regularly, Food Analysis Performance Assessment Scheme (FAPAS) organizes interlaboratory trials for quality assessment and validation of acrylamide methods in a proficiency testing scheme. Proficiency tests have shown that two main approaches are used for acrylamide: HPLC coupled to tandem mass spectrometry (MS/MS) and GC of the mono- or dibromo derivative of acrylamide with electron ionization and mass spectrometry detection of the fragment ions.

Selection of the most appropriate analytical protocol should be based on the type of food product (sample matrix), acrylamide structure and its physical-chemical properties. Acrylamide is a reactive electrophile and due to its alpha, beta-unsaturated structure can react with nucleophiles such as amines, carboxylates, and thiols. Acrylamide has a low-molecular mass $(71.08 \mathrm{~g} / \mathrm{mol})$, high polarity, very good water solubility $(215.5 \mathrm{~g} / 100$ $\mathrm{ml}$ ), high reactivity, and low volatility. Besides, because of the lack of sufficiently strong chromophore groups (conjugated double or triple bonds, aromatic rings) in acrylamide molecules, and the lack of natural fluorescence, it cannot be measured by using spectrophotometric UV detectors. ${ }^{11}$ Among the many foods analyzed today, coffee is considered a difficult matrix due to the presence of interfering co-extractives, ${ }^{12,13}$ and many methods have been optimized for the determination of acrylamide in coffee and its substitutes. Coffee is a matrix with interferences and ion suppression. Indeed, preliminary data reported on acrylamide content in coffee was assumed to contain some bias and overestimation was suggested due to presence of interfering compounds.
Isotope dilution liquid or gas chromatography approaches, coupled to tandem mass spectrometry detectors, for the quantitative analysis of acrylamide is highly recommended in order to obtain reliable results. In literature, there are few exceptions, based on UV $\mathrm{UV}^{14}$ and electron capture detection. ${ }^{15}$ However, despite the selectivity of mass spectrometry and tandem mass spectrometry, the complexity of the food matrices requires a more or less intensive cleanup step during sample preparation in order to eliminate or reduce the presence of interfering compounds. Furthermore, sample preparation consisting of concentration of acrylamide and removal of interfering compounds is the crucial step in its analysis.

Rosen and Hellenäs ${ }^{16}$ and Tareke et al. $^{5}$ reported a pioneer study on the analysis of acrylamide in different heat-treated foods using the isotope dilution liquid chromatography coupled to mass spectrometry. This method was widely applied and further adapted to achieve the required precision and sensitivity for complex matrixes such as coffee. Other methods for analysis of acrylamide rely on analyte derivatization and/or gas chromatographic separation. Gas chromatography-mass spectrometry (GC-MS) methods have been used for the detection of acrylamide. GC methods include a derivatization of acrylamide such as bromination or the formation of a stable thioether by reaction with 2-mercaptobenzoic acid. The product of bromination is 2,3-dibromopropionamide, which can be back-extracted from the aqueous bromination solution into a solvent adequate for gas chromatographic analysis, or treated with triethylamide to form the more stable 2-bromopropionamide. Following removal of the ethyl acetate by evaporation, triethylamine is added to partially debrominate, after which the sample extracts are injected onto a GC-MS system for quantification. ${ }^{11,17}$ Gas chromatography-electron capture detector (GC-ECD) methods have also been described for rapid and low-cost analysis of acrylamide in foods. ${ }^{15}$

However, GC methods based on derivatization have some drawbacks that should be considered. Derivatization is time consuming and laborious with risk of analyte loss due to derivative instability or incomplete derivatization, and false positives due to side reactions or interferences from the derivatization reagent. The excess of bromine is removed by tritiation with a sodium thiosulphate solution. The resulting brominated acrylamide is less polar as compared to the original compound and therefore easily soluble in non polar organic solvent. The GC columns most commonly employed for the analysis of the bromo-derivative are midpolar to polar columns. Several GC capillary columns have been proposed, such as DB17 (50\%-phenyl-dimethylpolysiloxane), ZB50 (50\%-phenyl-dimethylpolysiloxane), Optima WAX (olyethyleneglycol $20 \mathrm{kDa}$ ), or RTX-200 Crossbond (trifluoropropylmethylpolysiloxane). Dimensions should be of $30 \mathrm{~m}$ of length and $0.25 \mathrm{~mm}$ of internal diameter 
with $0.25 \mu \mathrm{m}$ of thickness. For mass detectors, m/z 149: $\left[\mathrm{C}_{3} \mathrm{H}_{4}{ }^{79} \mathrm{BrNO}\right]^{+}$is selected for bromopropenamide identification and quantification, a part of 149 and 154 for additional identification. It is also important to consider that the bromination procedure involves the use of hazardous chemicals like bromine, which is very toxic by inhalation and likely to produce an increased risk to the technician. Some methods omit the time-consuming derivatization step and measure acrylamide directly after extraction and cleanup using GC-MS. ${ }^{18}$

Recently, a new method based on offline coupling of LC with GC in replacement of conventional sample preparation techniques for coffee has been proposed to analyze acrylamide in coffee brews. ${ }^{19}$ The method involves the fractionation of the sample by LC in a first step, concentration of the target fraction under nitrogen, and subsequent analysis by GC coupled with MS. This new approach allows the direct analysis of coffee brew without further sample manipulation, clarification, or cleaning steps. This procedure reach quantitation limits of $10 \mu \mathrm{g} / 1$ of acrylamide in brewed coffee.

This chapter will be focused in liquid chromatography approaches, although bromination GC-MS techniques also fulfil the requirements for acrylamide analysis in coffee. Next, the main stages for sample preparation and analysis are discussed.

\subsubsection{Sample Extraction}

Acrylamide is soluble in water, acetone, and ethanol; however, it is not soluble in nonpolar solvents. Thus, water at room temperature has been used to extract acrylamide from various sample matrices, including coffee, in most published analytical methods, since acrylamide is a good hydrophilic small molecule. Besides, methanol also can be used to extract acrylamide and precipitate co-extractives and later eliminated by rotator evaporation and concentration. There are many strategies proposed in the literature, but coffee has been identified as a difficult matrix and additional sample preparation steps are necessary. In case of coffee samples, it is recommended to reduce the mass ratio during extraction of about one part sample plus 20 part of water. ${ }^{20,21}$ Figure 111.2 shows a comprehensive flowchart for acrylamide analysis. In particular for coffee, an additional defatting step is recommended by using hexane, cyclohexane, or toluene before or in combination with the aqueous extraction. The sample should be finely ground with particles smaller than $1 \mathrm{~mm}$ in order to improve the extraction yield. Some sample preparations also include the addition of methanol, acetonitrile, or saline solution. Other procedures include precipitation of co-extractives with Carrez reagent (potassium ferricyanide (II) and zinc (II) sulfate (VI)). During the extraction and workup process, it is recommended to not exceed $40{ }^{\circ} \mathrm{C}$. Alternatively, extraction can be intensified

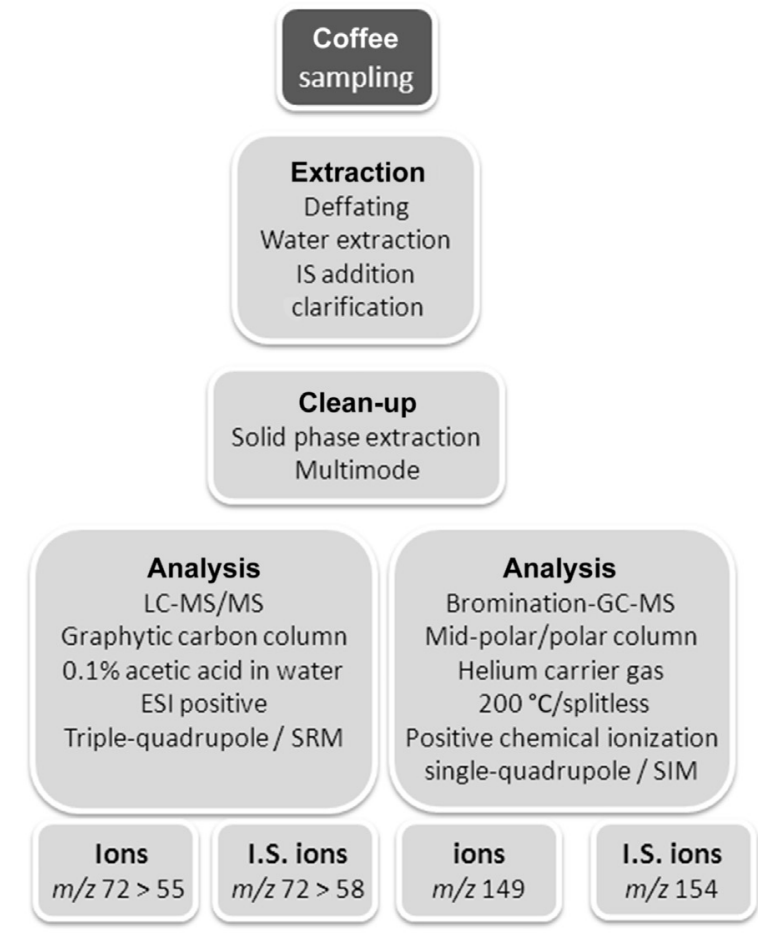

FIGURE 111.2 General scheme of acrylamide analysis in coffee by LC-MS/MS and bromination-GC-MS.

by ultrasound, accelerated by a solvent (ASE-accelerated solvent extraction), or conducted by using a supercritical fluid (SFE-supercritical fluid extraction). ${ }^{20}$

In order to control the recoveries and keep track of possible losses occurring during the whole sample pretreatment, an internal standard is added to the sample matrix after homogenization and before extraction. Most published studies have used carbon-labeled $\left({ }^{13} \mathrm{C}\right)$ or deuterium-labeled $\left(\mathrm{D}_{3}\right)$ acrylamide as internal standard. For GC methods, N,N-dimethylacrylamide, methacrylamide, and propionamide have also been used. At the end of the extraction, the aqueous phase may be centrifuged and conditions may vary from one laboratory to other. Some of them have used centrifugation filters or $3 \mathrm{kDa}$ ultrafiltration units.

However, certain pitfalls affecting the extraction of acrylamide have been described in the literature due to incomplete extraction and neo-formation of acrylamide during the extraction step. For instance, application of ASE for extraction of food samples with ethyl acetate at elevated temperature and pressure has given incomplete extraction. Furthermore, formation has also been suggested in the injection port during direct GC-MS analysis (if acrylamide precursors are present).

\subsubsection{Purification and Cleanup Step}

For LC-MS based methods, different solid-phase extraction (SPE) cartridges have been applied as an 
effective cleanup step to eliminate interfering compounds. The cleanup step could be achieved by using single or multiple SPE with different sorbents (silica, polymer, or carbon-based), or combinations of these (mixed mode). ${ }^{22}$ Different sorbent and commercially available cartridges have been used, such as Oasis MAX (mixed-mode anion exchange), Oasis MCX (mixed-mode cation exchange), Oasis HLB (Poly(divinyl-benzene-co$\mathrm{N}$-vinylpyrrolidone)), ENVI-Carb (graphitized carbon), Isolute Multimode (mixed mode containing nonpolar $\left(\mathrm{C}_{18}\right)$, strong cation exchange $\left(-\mathrm{SO}_{3}^{-}\right)$and strong anion exchange $\left(-\mathrm{NR}_{3}^{+}\right)$functional groups), Bond Elut C18 $\left(\mathrm{C}_{18}\right.$ hydrophobic silica-based encapped sorbent), Bond Elut Jr-PSA (anion exchange), Bond Elut Accucat, Bond Elut SCX (silica-based benzene sulphonic acid, nonendcapped), Strata-X-C (Polymeric resin functionalised with polar and strong cation exchange groups), Strata C18E ( $\mathrm{C}_{18}$ hydrophobic silica-based sorbent), Chromabond HR-XC (Polymeric resin functionalised with polar and strong cation exchange groups), Carbograph 4 (graphitised carbon), or Bakerbond $\mathrm{SiOH}$ (silica gel based sorbent), among others. Hydroxylated polystyrenedivinylbenzene copolymer phase $(\mathrm{ENV}+)$ gives the strongest retention. ${ }^{23}$ The phenolic groups on ENV + might enhance retention of acrylamide through hydrogen bonding with the amide function, which can act both as a hydrogen bond donor and acceptor. ${ }^{20}$

Recently, a method for the determination of acrylamide in roasted coffee was validated by a collaborative trial. The method was based on water extraction and simultaneous defatting with n-hexane. The aqueous phase was then purified by passage through two SPE columns: an Isolute Multimode followed by an Isolute Env+. ${ }^{23}$ Isolute Multimode (Biotage AB, Uppsala, Sweden) contains a silica-based C-18 group as well as anion and cation exchangers. Acrylamide is not retained in the column, but many matrix components (nonpolar and ionic compounds) that could exert interference are retained. At the second solid-phase extraction step, an Isolute ENV+ (Biotage AB, Uppsala, Sweden) cartridge that contains a polymer-based phase with high capacity to bind acrylamide is used. Isolute Env+ is an especially dedicated SPE column to retain highly polar compounds. Acrylamide is eluted with $60 \%$ methanol in water. This step also allows for concentration of the sample if necessary. This sample is ready for liquid chromatography after application of a nitrogen stream for solvent reduction. Figure 111.3 describes the sequence for cleanup for acrylamide analysis using the multimode solid-phase extraction. This cleanup step can be used for gas chromatography procedures. In this case, extracts are brominated, extracted with ethyl acetate, and dried over sodium sulfate. After removal of the ethyl acetate by evaporation, triethylamine is added for debromination, and the sample is ready for GC injection.

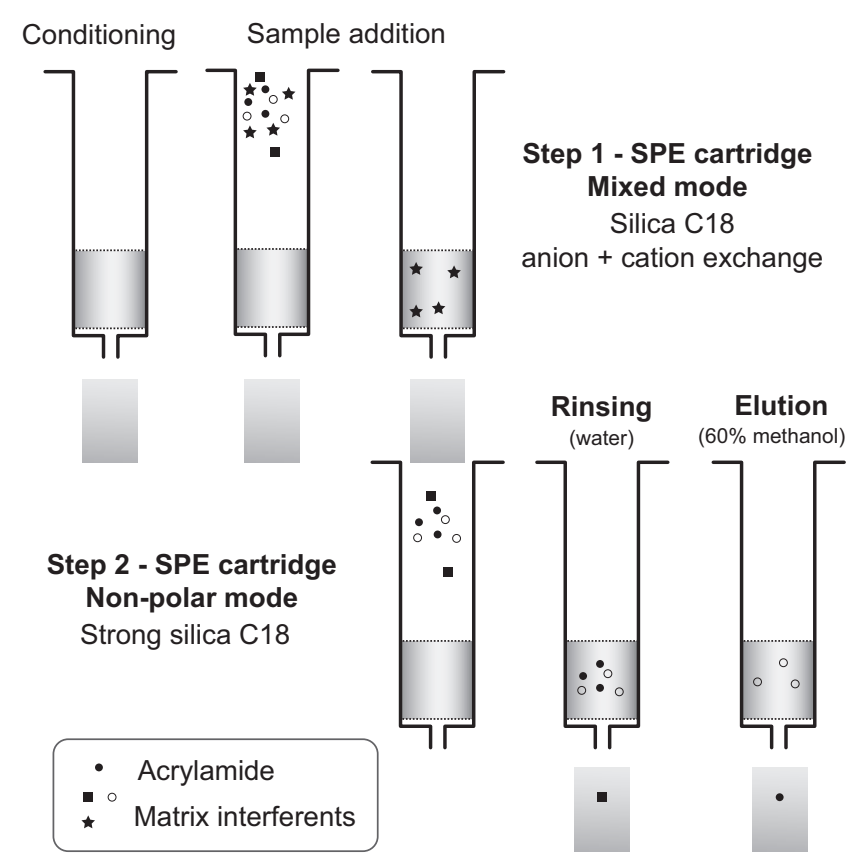

FIGURE 111.3 Scheme for sample cleanup following the multimode solid-phase extraction procedure for acrylamide analysis.

A smart alternative is the use of molecularly imprinted solid-phase extraction (MISPE) procedures that combine the advantages of both molecular recognition and traditional SPE methods, giving higher affinities, selectivities, and sensitivities. But the challenge is the development of effective molecularly imprinted polymers (MIPs) for acrylamide as a target molecule since it is used as a classical cross-linker. Recently Jiang et al. ${ }^{24}$ obtained a novel acrylamide molecularly imprinted material based on silica microparticles synthesized by a surface polymerization method using propionamide as a template molecule, methacrylic acid as a functional monomer, and ethylene glycol dimethacrylate as a cross-linker. Authors described a MIP-SPE/HPLC protocol that improved the selectivity and eliminated the effects of template leakage on quantitative analysis, and could be used for the determination of acrylamide in complex food samples.

Alternatively, a QuEChERS (Quick, Easy, Cheap, Effective, Rugged, and Safe) method based on water extraction and partition with acetonitrile by salting out with $\mathrm{MgSO}_{4}$ and $\mathrm{NaCl}$ has been reported with very promising results. ${ }^{25}$ Briefly, homogenized sample and spiked $d_{3}$-acrylamide is extracted with a mixture of hexane:water:acetonitrile (5:10:10) containing $\mathrm{MgSO}_{4}(4$ g) and $\mathrm{NaCl}(0.5 \mathrm{~g})$. The salt combination enhances separation of the water and acetonitrile layers. Acrylamide is mainly concentrated into the acetonitrile layer. In addition, the use of acetonitrile serves for deproteinization, and a simple centrifugation step is sufficient to clarify the extract. In a second step, acetonitrile extract is transfer to a microcentrifuge tube containing $50 \mathrm{mg}$ of the 
sorbent for dispersive solid-phase extraction and $150 \mathrm{mg}$ of anhydrous $\mathrm{MgSO}_{4}$. The final extract is analyzed either by liquid chromatography-tandem mass spectrometry or by gas chromatography-mass spectrometry.

\subsubsection{Chromatographic Separation and Detection}

Determination of the acrylamide concentration is most often assayed by high-performance liquid chromatography coupled with mass spectrometry (HPLC-MS). In particular, liquid chromatography coupled with tandem mass spectrometry (LC-MS/MS) is well suited to analyses of polar compounds such as acrylamide that are not sufficiently volatile to be quantitatively determined by gas chromatography coupled with mass spectrometry (GC-MS). Table 111.1 summarizes some procedures specially dedicated to coffee. LC-MS/MS enables omitting the time consuming step of derivatization that is necessary before GC-MS separation. There are a few exceptions in which UV and single quadrupole MS (SIM, single ion monitoring mode) were used. Most extended ionization methods used in LC-MS systems include electrospray ionization (ESI), although a few have reported good experience with atmospheric pressure chemical ionization (APCI), which are regarded as mild ionization techniques enabling detection of even very polar substances whose analysis is difficult and less susceptible to ion suppression. However, UV detection is performed at $202 \mathrm{~nm}$, which implies a lack of selectivity but it is not suitable for coffee analysis. For detection coupled to mass spectrophotometers, it is recommended that the column effluent is diverted to waste for the first minutes of running and then switched to the detector about 2 min before eluting of the acrylamide peak. ${ }^{23}$

For acrylamide analysis in coffee and derivatives, the application of tandem mass spectrometry working in multiple reaction monitoring mode (MRM) is recommended. MRM offers higher selectivity than SIM applied in a single quadrupole since the transition from a precursor ion to a product ion is monitored. The product ion is generated by collision in the second quadruple and monitored in the third one. Figure 111.4 shows the product ions obtained after fragmentation of acrylamide in mild conditions. The main ions observed for acrylamide are $m / z 72$, corresponding to the protonated molecular ion; $m / z 55$, corresponding to a loss of $\mathrm{NH}_{2}$; and $m / z 27$, corresponding to a subsequent loss of CO. For acrylamide quantitation, mass transition $72>55$ has been selected due to its high intensity. Then, the mass transitions such as $72>54,72>47$, and $72>27$ have been also used for confirmation. Respectively, transition of $75>58$ has been described for isotopic-labeled acrylamide, $\mathrm{D}_{3}$-acrylamide, and ${ }^{13} \mathrm{C}_{3}$-acrylamide. Adjustment of the mass spectrometer parameters is critical since equipment performed poorly below $100 \mathrm{Da}$. The acquisition of two selected monitoring traces fulfils the criteria required in the Commission Decision 2002/657/EC.

In liquid chromatographic approaches, the best retention is achieved with a phase comprising porous graphitic carbon using water as the mobile phase. However, acrylamide is a very polar molecule with poor retention on conventional LC reversed-phase sorbents, and despite the use of tandem mass spectrometry, more effort may need to be placed on efficient cleanup steps to avoid interference from co-extractives. For the mass spectrometry improvements, the effect of different atmospherepressure interfaces on the LC-MS/MS determination of acrylamide has been further demonstrated. However, most LC-MS/MS methods have been used ESI in the positive ion mode.

The first proficiency test on the determination of acrylamide in coffee was organized in summer 2003 by FAPAS. A total of 41 laboratories from 17 countries participated in the study. The assigned acrylamide content was $329 \mu \mathrm{g} / \mathrm{kg}$, which was close to the median value from nearly 300 monitoring results for roast-coffee samples in the EU database on acrylamide levels in food. In the literature, limits of detection between 3 and $20 \mu \mathrm{g} / \mathrm{kg}$ and limits of quantitation between 10 and $50 \mu \mathrm{g} / \mathrm{kg}$ are often reported. These levels are adequate to analysis of acrylamide in coffee. In 2009, the IRMM (Institute of Reference Materials and Measurements) concluded a collaborative trial based on an LC-MS/MS method. ${ }^{23}$ The main conclusions achieved to improve the determination of acrylamide in coffee were to reduce the sample load into the SPE cartridge and to apply a previous extraction with hexane, since rapid loss of performance of the system after several injections and severe ion suppression was reported.

\subsection{OCCURENCE OF ACRYLAMIDE IN COFFEE}

European Commission Recommendation 2007/331/ EC4, dated 3 May 2007, on the monitoring of acrylamide levels in food required member states, including Norway, to perform annually in 2007, 2008, and 2009 the monitoring of acrylamide levels in certain foodstuffs. Some conclusions have arisen, and the upper bound mean of acrylamide levels ranged from $37 \mu \mathrm{g} / \mathrm{kg}$ for soft bread to $1504 \mu \mathrm{g} / \mathrm{kg}$ for substitute coffee. The highest 95th percentile value was reported for substitute coffee at 3976 $\mu \mathrm{g} / \mathrm{kg}$, and the highest maximum value for potato chips at $4804 \mu \mathrm{g} / \mathrm{kg}$. 33

The intensity of acrylamide formation in foods depends on initial concentrations of asparagine and reducing sugars and their ratio, as well as on temperature and duration of thermal treatment, water activity, and $\mathrm{pH}^{7}$. The free 
TABLE 111.1 Description of a Number of Methods for Acrylamide Analysis in Coffee Based on Liquid Chromatography Coupled to Mass Spectrometry

\begin{tabular}{|c|c|c|c|c|c|c|c|c|c|}
\hline Method & Extraction & Clarification & SPE Cartridge & I.S. & Mobile Phase & Column & Recovery & $\begin{array}{l}\mathrm{LOD} / \mathrm{LOQ} \\
(\mu \mathrm{gg} / \mathrm{kg})\end{array}$ & References \\
\hline LC-MS/MS-ESI & Water & Carrez I + II & Isolute multimode & $\mathrm{D}_{3}$-acrylamide & $\begin{array}{l}0.1 \% \text { Of acetic } \\
\text { acid }\end{array}$ & $\begin{array}{l}\mu \text {-Bondapak C18 } 300 \times \\
3.9 \mathrm{~mm} ; 10 \mu \mathrm{m}\end{array}$ & $93-99$ & $10 / 20$ & 26 \\
\hline LC-MS/MS-ESI & Water & None & $\begin{array}{l}\text { Strong cation } \\
\text { (SCX) and anion } \\
\text { exchange (SAX) }\end{array}$ & $\mathrm{D}_{3}$-acrylamide & $\begin{array}{l}0.1 \% \text { Formic } \\
\text { acid in water; } \\
\text { methanol }(3 \%)\end{array}$ & $\begin{array}{l}\text { Synergi Hydro } 250 \times \\
2.0 \mathrm{~mm} ; 4 \mu \mathrm{m}\end{array}$ & $92-95$ & $5 / 16$ & 22 \\
\hline LC-MS/MS-ESI & Water & None & $\begin{array}{l}\text { Automatic } \\
\text { multimode solid- } \\
\text { phase extraction }\end{array}$ & $\mathrm{D}_{3}$-acrylamide & $\begin{array}{l}0.1 \% \text { Formic acid } \\
\text { in water }\end{array}$ & $\begin{array}{l}\text { Hypercarb } 50 \times 2.1 \mathrm{~mm} \text {; } \\
5 \mu \mathrm{m}\end{array}$ & $96-100$ & $2 /-^{a}$ & 27 \\
\hline LC-MS/MS-ESI & $\begin{array}{l}\text { Water }+ \\
\text { dichloromethane } \\
+\mathrm{NaCl}\end{array}$ & $\begin{array}{l}\text { Carrez I + II; } \\
\text { ethyl acetate }\end{array}$ & $\begin{array}{l}\text { Isolute multimode } \\
\text { cartridge }\end{array}$ & $\mathrm{D}_{3}$-acrylamide & $\begin{array}{l}\text { Methanol/ } \\
\text { water/formic } \\
\text { acid 30/70/0.007 } \\
(\mathrm{v} / \mathrm{v} / \mathrm{v})\end{array}$ & $\begin{array}{l}\text { Shodex RSpak DE-413L } 250 \\
\times 4.6 \mathrm{~mm}\end{array}$ & & $9 / 13$ & 12 \\
\hline LC-MS-APCI & Methanol & Carrez I + II & $\begin{array}{l}\text { Oasis HLB solid- } \\
\text { phase extraction }\end{array}$ & $\begin{array}{l}{ }^{13} \mathrm{C}_{3^{-}} \\
\text {acrylamide }\end{array}$ & $\begin{array}{l}0.01 \mathrm{mM} \text { acetic } \\
\text { acid in } 0.2 \% \\
\text { aqueous solution } \\
\text { of formic acid }\end{array}$ & $\begin{array}{l}\text { Inertsil ODS-3250 × } 4.6 \mathrm{~mm} \text {; } \\
5 \mu \mathrm{m}\end{array}$ & 99-102 & $2 / 6$ & 28 \\
\hline $\begin{array}{l}\text { LC-MS/MS- } \\
\text { APCI }\end{array}$ & $\begin{array}{l}\text { Water }+ \\
\text { dichloromethane } \\
+ \text { ethyl acetate }+ \\
\text { acetonitrile }\end{array}$ & $\begin{array}{l}\text { Cyclohexane } \\
+ \text { pentane }+ \\
\text { acetone }\end{array}$ & $\begin{array}{l}\text { Aminopropyl- } \\
\text { bonded silica }\end{array}$ & $\begin{array}{l}{ }^{13} \mathrm{C}_{3^{-}} \\
\text {acrylamide }\end{array}$ & Water & Hypercarb $150 \times 2.1 ; 5 \mu \mathrm{m}$ & & $12.3 /-$ & 29 \\
\hline LC-MS/MS-ESI & Water & $\begin{array}{l}\text { Centriplus } \\
\text { YM-3 }\end{array}$ & $\begin{array}{l}\text { Isolute multimode } \\
\text { Oasis HLB + bond } \\
\text { elute Accucat }\end{array}$ & $\mathrm{D}_{3}$-acrylamide & $\begin{array}{l}5 \% \text { Methanol in } \\
\text { water }\end{array}$ & $\begin{array}{l}\text { Hypercarb } 100 \times 2.1 \mathrm{~mm}, \\
5 \mu \mathrm{m}\end{array}$ & $98-109$ & $34 / 75$ & 30 \\
\hline LC-MS-API-ES & $\begin{array}{l}\text { Hexane + cold } \\
\text { water }\end{array}$ & None & $\begin{array}{l}\text { Bond elut } \\
\text { Accucat \& } \\
\text { Derivatization with } \\
\text { 2-mercaptobenzoic } \\
\text { acid }\end{array}$ & $\begin{array}{l}{ }^{13} \mathrm{C}_{3^{-}} \\
\text {acrylamide }\end{array}$ & $\begin{array}{l}30 \% \text { Acetonitrile } \\
\text { and } 70 \% \text { Acetic } \\
\text { acid }(0.1 \%)\end{array}$ & $\begin{array}{l}\text { Phenyl-hexyl } 150 \times 3 \times \mathrm{mm} \text {; } \\
3 \mu \mathrm{m}\end{array}$ & 45 & $157 / 270$ & 31 \\
\hline LC-MS/MS-ESI & Water & None & $\begin{array}{l}\text { Oasis HLB + bond } \\
\text { Elut-Accucat }\end{array}$ & $\begin{array}{l}{ }^{13} \mathrm{C}_{3^{-}} \\
\text {acrylamide }\end{array}$ & $\begin{array}{l}0.5 \% \text { Methanol in } \\
\text { water }\end{array}$ & $\begin{array}{l}\text { Synergi Hydro-RP } 250 \times \\
2.0 \times \mathrm{mm} ; 4 \mu \mathrm{m}\end{array}$ & 92 & $-/ 10$ & 32 \\
\hline LC-MS/MS-ESI & Water + hexane & None & $\begin{array}{l}\text { Isolute multimode }+ \\
\text { Isolute ENV+ }\end{array}$ & $\mathrm{D}_{3}$-acrylamide & $\begin{array}{l}0.1 \% \text { Acetic acid in } \\
\text { water }\end{array}$ & Hypercarb $50 \times 2.1 \mathrm{~mm}$ & & & 23 \\
\hline
\end{tabular}

Internal standard (I.S.)

${ }^{a} \mu g / l$. 
asparagine concentrations in green coffee beans are within a very narrow range, typically $0.2-10 \mathrm{~g} / \mathrm{kg}$, with, on average, slightly higher levels in robusta beans. ${ }^{31,34,35}$ Levels of acrylamide in the product depend on the rate the formation and elimination of acrylamide, since this compound is not a final product of reaction. An important intermediate in the reaction pathway is 3-aminopropionamide (3-APA), detected in several foods, such as potatoes, cocoa, and cereal products, at concentrations comparable or slightly higher than acrylamide. ${ }^{36}$ Concentration of 3-APA is coffee products has been described in the range from 122 to $241 \mu \mathrm{g} / \mathrm{kg}$. Deamination of 3-APA provides a very good yield of acrylamide, depending on the reaction conditions. 3-APA is a transient intermediate in acrylamide formation.

A comprehensive study on levels of acrylamide in different food matrices was reported by Wenzl and Anklam, ${ }^{37}$ and specifically to coffee by Guenther et al. ${ }^{10}$ Acrylamide is found at levels of $200 \mathrm{mg} / \mathrm{kg}$ (maximum $958 \mathrm{mg} / \mathrm{kg}$ ) and $188 \mathrm{mg} / \mathrm{kg}$ (maximum $1047 \mathrm{mg} / \mathrm{kg}$ ) in roasted and instant coffee, respectively. ${ }^{33}$ Other studies reported the concentration of acrylamide in roast and ground coffee samples in the range from 45 to 539 $\mu \mathrm{g} / \mathrm{kg}, 12,32,38$ and there are no significant differences in acrylamide formation in normal or decaffeinated coffee. Due to its high polarity and water solubility, acrylamide is largely extracted in the brew. It has been described at levels of $25 \mu \mathrm{g} / 1$ in ready-to-drink coffees and filtered coffee, and $10 \mu \mathrm{g} / 1$ in instant coffee. Assuming an average acrylamide content of $250 \mu \mathrm{g} / \mathrm{kg}$ in the powder and a brew strength of $50 \mathrm{~g} / 1$ (5\% in brewed coffee), then 1 1 coffee (six to eight cups) will result in an acrylamide uptake of $12.5 \mu \mathrm{g}$ (considering total extraction of the acrylamide from the powder). ${ }^{10}$ The U.S. Food and Drug

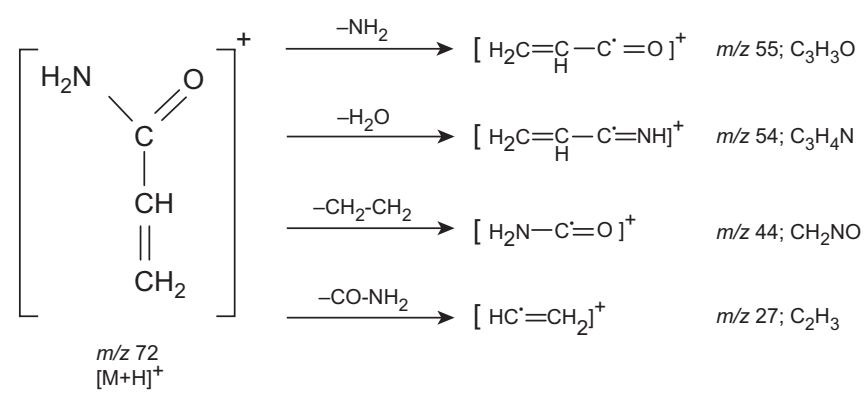

FIGURE 111.4 Scheme of acrylamide fragmentation in its respective products ions.
Administration (FDA) reported levels of acrylamide in brewed coffee from 6 to $16 \mu \mathrm{g} / 1 .{ }^{39}$ In 2011, the European Commission set an indicative value of $450 \mu \mathrm{g} / \mathrm{kg}$ for roasted coffee and $900 \mu \mathrm{g} / \mathrm{kg}$ for soluble instant coffee. ${ }^{40}$ This fact is logical, since soluble coffee is prepared by extraction of roasted beans with hot water under pressure, and acrylamide is completely extracted. Then the coffee brew is dried and subsequently acrylamide is concentrated in the powder. Table 111.2 summarizes the latest levels of acrylamide found in Europe for coffee.

However, there is some controversy regarding the measurement of acrylamide in coffee. since values decrease with storage time and temperature. ${ }^{12,23,42}$ Losses of $40-60 \%$ have been recorded in ground coffees stored at room temperature. In this context, Baum et al. ${ }^{43}$ confirmed that close to $90 \%$ of acrylamide remained firmly bound to the coffee matrix. and it was hypothesized that acrylamide might be integrated with material eluting into the brew together with colouring material. Pastoriza et al. ${ }^{44}$ showed that nucleophilic amino groups of amino acids from the proteinaceous backbone of melanoidins react via the Michael addition reaction with acrylamide, although the exact mechanism is unknown. Melanoidins could modulate the reaction pathway of acrylamide formation and elimination during coffee roasting and serve as acrylamide-mitigation substance.

The mean acrylamide intake for adults ( $>18$ years) in Europe was estimated to range between 0.31 and $1.1 \mu \mathrm{g} / \mathrm{kg}$ b.w. per day and the 95th percentile between 0.58 and 2.3 $\mu \mathrm{g} / \mathrm{kg}$ b.w. per day. ${ }^{40}$ Although bakery products together with potato derivatives are the most important sources of acrylamide, coffee was identified as a main contributor to the dietary exposure to acrylamide. The contribution of coffee to the dietary daily intake of acrylamide is significant in countries with high coffee consumption. It is expected that acrylamide intake through coffee consumption varies widely demographically and geographically. Furthermore, the contribution of coffee to the dietary daily intake of acrylamide is significant in countries with high coffee consumption. For instance, coffee consumption in adults accounts for about $30 \%$ of acrylamide intake in Norway, $40 \%$ in Sweden, $8 \%$ in the Netherlands, $13 \%$ in the United States, $20 \%$ for Denmark, $36 \%$ in Switzerland, and 28\% in France. $7,27,45$

Since the presence of naturally formed acrylamide in foods was detected, different mitigation strategies have

TABLE 111.2 Latest Levels of Acrylamide $(\mu \mathrm{g} / \mathrm{kg})$ Distribution in Coffee and Coffee Substitutes in Europe in 2010

\begin{tabular}{llllcccc}
\hline Product & Indicative Value & $n$ & Median & Mean & P90 & P95 & Maximum \\
\hline Roast coffee & 450 & 103 & 200 & 256 & 462 & 641 & 1932 \\
Instant coffee & 900 & 15 & 520 & 1123 & 2629 & 8044 & 8044 \\
Coffee substitute & & 24 & 870 & 1350 & 3300 & 3400 & 4200 \\
\hline
\end{tabular}

Levels are reported by the European Food Safety Authority ${ }^{41}$ P90, 90th percentile; P95, 95th percentile; $n$, number of samples. 
been attempted. Over the past years, the experiences of the food industry and scientists working on acrylamide mitigation in the pertinent product categories have been collected in a guidance document termed the Food Drink Europe (FDE, formerly named Confederation of the European Food and Drink Industries, CIAA) Toolbox. ${ }^{46}$ Nowadays, there is not an effective strategy of acrylamide mitigation or alternative processes applicable for coffee and its derivatives. The European coffee industry is continuously updating information on the fate of acrylamide during processing, storage, and brewing of coffee. Acrylamide and melanoidins are both Maillard reaction products formed during the roasting of coffee, typically conducted at temperatures between 220 and $250{ }^{\circ} \mathrm{C}$. Theoretically, any attempt to inhibit the Maillard reaction as a possible measure to minimize the formation of acrylamide would lead to a reduction of the antioxidant capacity of coffee. ${ }^{47}$

\subsection{SUMMARY POINTS}

- Acrylamide is a processing contaminants naturally formed during roasting of coffee.

- Coffee is one of the most relevant contributors to the dietary daily intake of acrylamide.

- Although there is no regulation for maximum acrylamide content in coffee products, the European Commission in 2011 settled upon an indicative value of $450 \mu \mathrm{g} / \mathrm{kg}$ and $900 \mu \mathrm{g} / \mathrm{kg}$ for roasted and instant coffee, respectively.

- Final concentration of acrylamide in coffee is a result of concurrent formation from precursors and elimination reactions.

- Analytical approaches based on both liquid and gas chromatography coupled to mass spectrometry are adequate to assess the levels of acrylamide within standards of precision and accuracy.

- Coffee is a difficult matrix for acrylamide evaluation, due to the presence of several co-extractives and ion suppression being recommended and additional extraction with hexane.

- A draft for an official method of acrylamide in foods has already been established by the European Committee of Normalization.

- Levels of acrylamide decrease during storage of coffee, since it might be integrated into the highmolecular-weight polymers (melanoidins).

\section{References}

1. Friedman M. Chemistry, biochemistry, and safety of acrylamide. A review. J Agric Food Chem 2003;51:4504-26.

2. European Commission. Commission Regulation (EU) No 10/2011 of 14 January 2011 on plastic materials and articles intended to come into contact with food. Off J Eur Union 2011;L12:1-89.
3. European Commission. Council Directive 98/83/EC on the quality of water intended for human consumption. Off J 1998;L330:32-54.

4. Tareke E, Rydberg P, Karlsson P, Eriksson S, Tornqvist M. Acrylamide: a cooking carcinogen? Chem Res Toxicol 2000;13:517-22.

5. Tareke E, Rydberg P, Karlsson P, Eriksson S, Tornqvist M. Analysis of acrylamide, a carcinogen formed in heated foodstuffs. I Agric Food Chem 2002;50:4998-5006.

6. Shipp A, Lawrence G, Gentry R, McDonald T, Bartow H, Bounds J, et al. Acrylamide: review of toxicity data and dose-response analyses for cancer and noncancer effects. Crit Rev Toxicol 2006;36:481-608.

7. Friedman M, Levin CE. Review of methods for the reduction of dietary content and toxicity of acrylamide. J Agric Food Chem 2008; 56:6113-40.

8. Hogervorst J, Schouten L, van den Brandt P. Reaction on Gargas et al:: acrylamide: consideration of species differences and nonlinear processes in estimating risk and safety for human ingestion. Food Chem Toxicol 2009;47:2871-2.

9. FAO/WHO Experts Committee on Food Additives (JECFA). Summary and conclusions of the sixty-fourth meeting of the Joint FAO/WHO Experts Committee on Food Additives (JECFA); 2005. Rome, February 8-17, 2005, JECFA/64/SC.

10. Guenther H, Anklam E, Wenzl T, Stadler RH. Acrylamide in coffee: review of progress in analysis, formation and level reduction. Food Addit Contam 2007;24:S60-70.

11. Zhang Y, Ren Y, Zhang Y. New research developments on acrylamide: analytical chemistry, formation mechanism, and mitigation recipes. Chem Rev 2009;109:4375-97.

12. Delatour T, Périsset A, Goldmann T, Riediker S, Stadler RH. Improved sample preparation to determine acrylamide in difficult matrixes such as chocolate powder, cocoa, and coffee by liquid chromatography tandem mass spectroscopy. I Agric Food Chem 2004;52:4625-31.

13. Riediker S, Stadler RH. Analysis of acrylamide in food by isotopedilution liquid chromatography coupled with electrospray ionization tandem mass spectrometry. J Chromatogr A 2003;1020:121-30.

14. Gökmen V, Senyuva HZ, Acar J, Sarıglu K. Determination of acrylamide in potato chips and crisps by high-performance liquid chromatography. J Chromatogr A 2005;1088:193-9.

15. Zhu Y, Li G, Duan Y, Chen S, Zhang C, Li Y. Application of the standard addition method for the determination of acrylamide in heat-processed starchy foods by gas chromatography with electron capture detector. Food Chem 2008;109:899-908.

16. Rosen J, Hellenas KE. Analysis of acrylamide in cooked foods by liquid chromatography tandem mass spectrometry. Analyst 2002;127:880-2.

17. Alves RC, Soares C, Casal S, Fernandes JO, Oliveira MBPP. Acrylamide in espresso coffee: Influence of species, roast degree and brew length. Food Chem 2010;119:929-34.

18. Tateo F, Bononi M, Andreoli G. Acrylamide levels in cooked rice, tomato sauces and some fast food on the Italian market. J Food Compos Anal 2007;20:232-5.

19. Blanch GP, Morales FJ, Moreno Fde L, del Castillo ML. A new approach based on off-line coupling of high-performance liquid chromatography with gas chromatography-mass spectrometry to determine acrylamide in coffee brew. J Sep Sci 2013;36:320-4.

20. Petersson EV, Rosen J, Turner C, Danielsson R, Hellenas KE. Critical factors and pitfalls affecting the extraction of acrylamide from foods: an optimisation study. Anal Chim Acta 2006;557:287-95.

21. Gokmen V, Morales FJ, Atac B, Serpen A, Arribas-Lorenzo G. Multiple-stage extraction strategy for the determination of acrylamide in foods. J Food Compos Anal 2009;22:142-7.

22. Bortolomeazzi R, Munari M, Anese M, Verardo G. Rapid mixed mode solid phase extraction method for the determination of acrylamide in roasted coffee by HPLC-MS/MS. Food Chem 2012;135:2687-93. 
23. Wenzl T, Szilagyi S, Rosen J, Karasek L. Validation by collaborative trial of an isotope dilution liquid chromatographic tandem mass spectrometric method to determine the content of acrylamide in roasted coffee. Food Addit Contam A 2009;26:1146-52.

24. Jiang D, Suna X, Zhang Y. Preparation and application of acrylamide molecularly imprinted composite solid-phase extraction materials. Anal Method 2012;4:3760-6.

25. Mastovska K, Lehotay SJ. Rapid sample preparation method for LC-MS/MS or GC-MS analysis of acrylamide in various food matrices. J Agric Food Chem 2006;54:7001-8.

26. Arisseto A, de Figueiredo Toledo M, Govaert Y, van Loco J, Fraselle S, Degroodt JM. A modified sample preparation for acrylamide determination in Cocoa and coffee products. Food Anal Method 2008;1:49-55.

27. Granby K, Fagt S. Analysis of acrylamide in coffee and dietary exposure to acrylamide from coffee. Anal Chim Acta 2004;520:177-82.

28. Gökmen V, Senyuva HZ. A generic method for the determination of acrylamide in thermally processed foods. J Chromatogr A 2006;1120:194-8.

29. Aguas P, Fitzhenry M, Giannikopoulos G, Varelis P. Analysis of acrylamide in coffee and cocoa by isotope dilution liquid chromatography-tandem mass spectrometry. Anal Bioanal Chem 2006; 385:1526-31.

30. Eerola S, Hollebekkers K, Hallikainen A, Peltonen K. Acrylamide levels in Finnish foodstuffs analysed with liquid chromatography tandem mass spectrometry. Mol Nutr Food Res 2007;51:239-47.

31. Bagdonaite K, Derler K, Murkovic M. Determination of acrylamide during roasting of coffee. J Agric Food Chem 2008;56:6081-6.

32. Andrzejewski D, Roach JAG, Gay ML, Musser SM. Analysis of coffee for the presence of acrylamide by LC-MS/MS. J Agric Food Chem 2004;52:1996-2002.

33. European Food Safety Authority (EFSA). Results on acrylamide levels in food from monitoring years 2007-2009 and exposure assessment. EFSA J 2011;9:2133.

34. Stadler RH, Scholz G. Acrylamide: an update on current knowledge in analysis, levels in food, mechanisms of formation, and potential strategies of control. Nutr Rev 2004;62:449-67.

35. Lantz I, Ternite R, Wilkens J, Hoenicke K, Guenther H, van der Stegen GHD. Studies on acrylamide levels in roasting, storage and brewing of coffee. Mol Nutr Food Res 2006;50:1039-46.
36. Granvogl M, Schieberle P. Thermally generated 3-aminopropionamide as a transient intermediate in the formation of acrylamide. J Agric Food Chem 2006;54:5933-8.

37. Wenzl T, Anklam E. European Union database of acrylamide levels in food: update and critical review of data collection. Food Addit Contam 2007;24:S5-12.

38. Senyuva HZ, Gökmen V. Study of acrylamide in coffee using an improved liquid chromatography mass spectrometry method: Investigation of colour changes and acrylamide formation in coffee during roasting. Food Addit Contam 2005;22:214-20.

39. FDA. Survey data on acrylamide in Food: Individual food products; 2006 [accessed 02.03.13]. http://www.fda.gov/Food/FoodborneIllness Contaminants/ChemicalContaminants/ucm053549.htm.

40. European Commission. Commission recommendation of 10.1.2011 on investigations into the levels of acrylamide in food; 2011.

41. European Food Safety Authority (EFSA) Parma, Italy. Update on acrylamide levels in food from monitoring years 2007 to 2010. EFSA J 2012;10:2938.

42. Hoenicke K, Gatermann R. Studies on the stability of acrylamide in food during storage. J AOAC Int 2005;88:268-73.

43. Baum M, Böhm N, Görlitz J, Lantz I, Merz KH, Ternité R, et al. Fate of 14C-acrylamide in roasted and ground coffee during storage. Mol Nutr Food Res 2008;52:600-8.

44. Pastoriza S, Rufián-Henares JÁ, Morales FJ. Reactivity of acrylamide with coffee melanoidins in model systems. LWT-Food Sci Technol 2012:45:198-203.

45. Sirot V, Hommet F, Tard A, Leblanc JC. Dietary acrylamide exposure of the French population: results of the second French Total Diet Study. Food Chem Toxicol 2012;50:889-94.

46. FDE. Food drink europe acrylamide toolbox; 2011 [accessed 15.03.13]. http:/ / fooddrinkeurope.eu/uploads/publications_documents / Toolboxfinal260911.pdf.

47. Summa CA, de la Calle B, Brohee M, Stadler RH, Anklam E. Impact of the roasting degree of coffee on the in vitro radical scavenging capacity and content of acrylamide. LWT-Food Sci Technol 2007;40:1849-54. 